Review

\title{
Contribution of soil respiration to the global carbon equation ${ }^{\text {is }}$
}

\author{
Ming $\mathrm{Xu}^{\mathrm{a}, \mathrm{b}, *}$, Hua Shang ${ }^{\mathrm{a}}$ \\ a Department of Ecology, Evolution and Natural Resources, Rutgers University, 14 College Farm Road, New Brunswick, NJ 08901, USA \\ ${ }^{\mathrm{b}}$ Key Laboratory of Ecosystem Network Observation and Modeling, Institute of Geographic Sciences and Natural Resources Research, Chinese Academy of \\ Sciences, Beijing, China
}

\section{A R T I C L E I N F O}

\section{Article history:}

Received 4 May 2016

Received in revised form 16 August 2016

Accepted 18 August 2016

Available online 31 August 2016

\section{Keywords:}

Soil microbial decomposition

Soil respiration measurement

Soil respiration model

Global annual soil respiration

Belowground carbon allocation

\begin{abstract}
A B S T R A C T
Soil respiration (Rs) is the second largest carbon flux next to GPP between the terrestrial ecosystem (the largest organic carbon pool) and the atmosphere at a global scale. Given their critical role in the global carbon cycle, Rs measurement and modeling issues have been well reviewed in previous studies. In this paper, we briefly review advances in soil organic carbon (SOC) decomposition processes and the factors affecting Rs. We examine the spatial and temporal distribution of Rs measurements available in the literature and found that most of the measurements were conducted in North America, Europe, and East Asia, with major gaps in Africa, East Europe, North Asia, Southeast Asia, and Australia, especially in dry ecosystems. We discuss the potential problems of measuring Rs on slope soils and propose using obliquely-cut soil collars to solve the existing problems. We synthesize previous estimates of global Rs flux and find that the estimates ranged from $50 \mathrm{PgC} / \mathrm{yr}$ to $98 \mathrm{PgC} / \mathrm{yr}$ and the error associated with each estimation was also high (4 PgC/yr to 33.2 PgC/yr). Using a newly integrated database of Rs measurements and the MODIS vegetation map, we estimate that the global annual Rs flux is $94.3 \mathrm{PgC} / \mathrm{yr}$ with an estimation error of $17.9 \mathrm{PgC} / \mathrm{yr}$ at a $95 \%$ confidence level. The uneven distribution of Rs measurements limits our ability to improve the accuracy of estimation. Based on the global estimation of Rs flux, we found that Rs is highly correlated with GPP and NPP at the biome level, highlighting the role of Rs in global carbon budgets.
\end{abstract}

(C) 2016 Published by Elsevier GmbH.

\section{Contents}

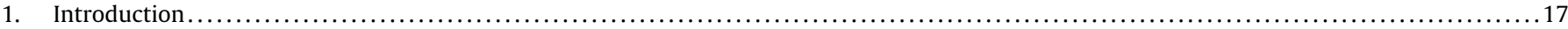

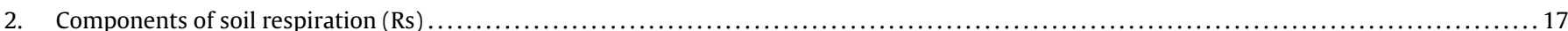

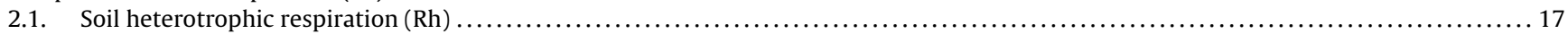

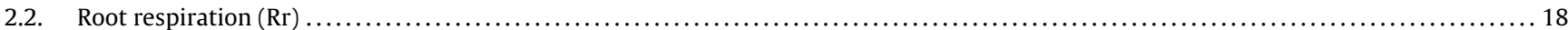

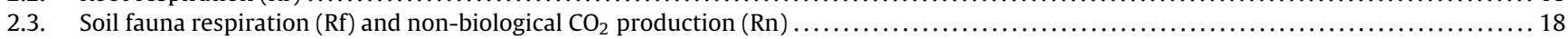

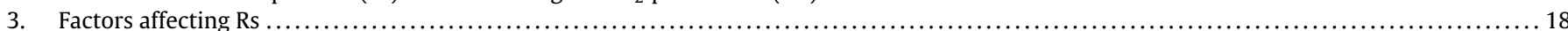

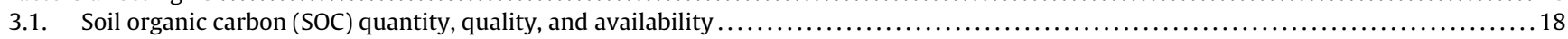

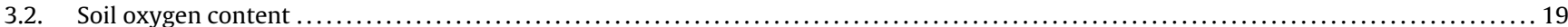

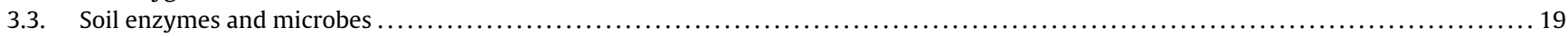

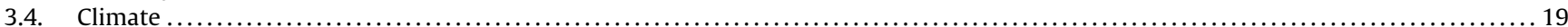

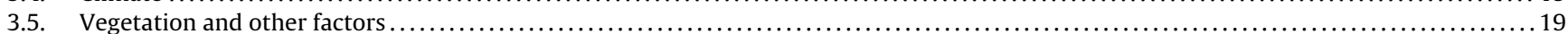

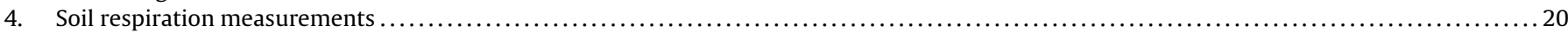

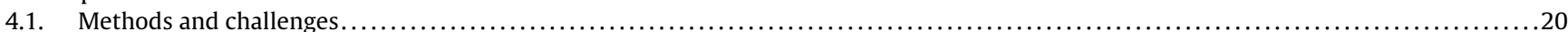

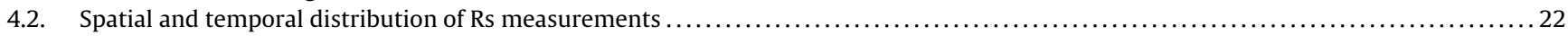

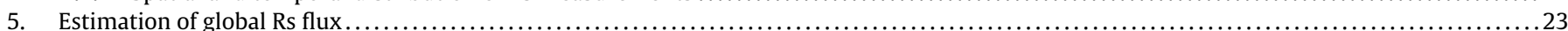

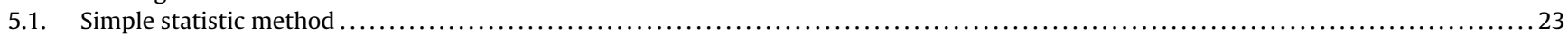

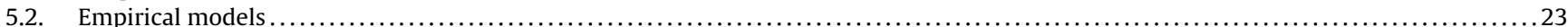

\footnotetext{
is This article is part of a special section entitled "Plants facing Changing Climate", published in the Journal of Plant Physiology $203,2016$.

* Corresponding author at: Department of Ecology, Evolution and Natural Resources, Rutgers University, 14 College Farm Road, New Brunswick, NJ 08901, USA.

E-mail address: mingxu@crssa.rutgers.edu (M. Xu).
} 


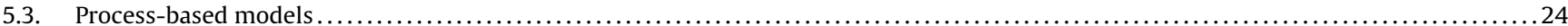

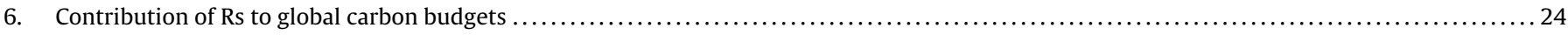

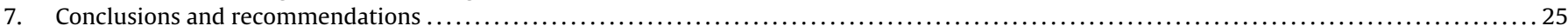

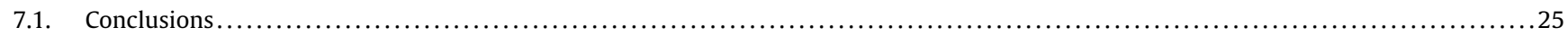

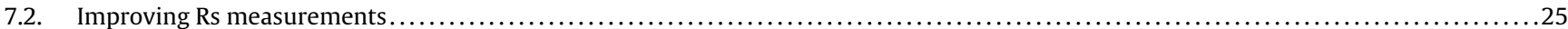

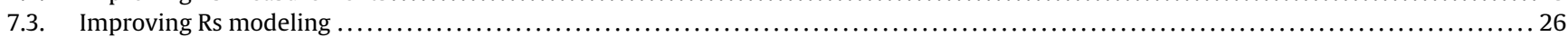

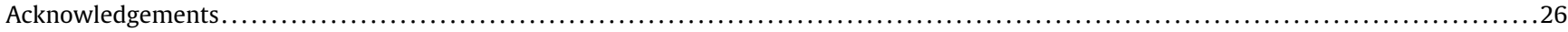

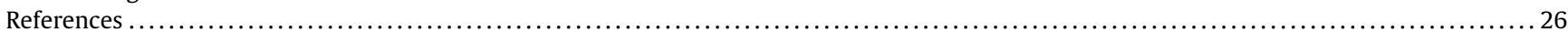

\section{Introduction}

Soil respiration (Rs) commonly refers to the $\mathrm{CO}_{2}$ efflux from the soil surface to the atmosphere. The annual $\mathrm{CO}_{2}$ emission through Rs at the global scale is about ten times that from current fossil fuel emissions (Bond-Lamberty and Thomson, 2010a). Apparently, soil respiration is critical to the global carbon cycle because global soils store as twice much carbon as the atmosphere (Post et al., 1982; IPCC, 2013; Scharlemann et al., 2014) and the ecosystem feedback through Rs is important to the projection of future atmospheric $\mathrm{CO}_{2}$ concentrations (Cox et al., 2000; Heimann and Reichstein, 2008). In addition, the Coupled Carbon Cycle Climate Model Intercomparison Project (CMIP4 and CMIP5) also pointed out that the uncertainty in projecting future global temperature was largely due to a poor understanding of the land carbon cycle (Friedlingstein et al., 2006; Friedlingstein et al., 2014).

The measured Rs at the soil's surface may come from multiple sources, such as root respiration $(\mathrm{Rr})$, heterotrophic respiration (Rh), soil fauna respiration (Rf), and non-biological $\mathrm{CO}_{2}$ production (Rn). Rr includes root maintenance respiration, where the respired energy is used for keeping roots alive, root growth respiration for growing new roots or new root tissues, and rhizospheric respiration $(\mathrm{Rz})$, where microbes respire $\mathrm{CO}_{2}$ in the rhizosphere by feeding on root exudates. $\mathrm{Rh}$ is due to the decomposition of dead organic matter by microbes in bulk soils. Rf includes the respiration from soil fauna, such as earthworms, ants, beetles, earwigs, and woodlice. Rn comes from soil chemical and physical processes, such as the $\mathrm{CO}_{2}$ released from soil solutions when water is evaporated or $\mathrm{CO}_{2}$ solubility changes with soil temperature fluctuation.

The soil $\mathrm{CO}_{2}$ efflux measured at the soil's surface is often assumed to approximate the "true soil respiration," though this assumption has been recently challenged by the finding that respired $\mathrm{CO}_{2}$ may be dissolved in soil solutions (Emmerich, 2003; Hastings et al., 2005; Stevenson and Verburg, 2006; Schlesinger et al., 2009; Tamir et al., 2011; Ma et al., 2013; Roland et al., 2013; Angert et al., 2015) or root xylem water and carried upward in the transpiration stream (Aubrey and Teskey, 2009; Bloemen et al., 2013). Nevertheless, some studies have shown that the ratio of soil surface $\mathrm{CO}_{2}$ efflux to $\mathrm{O}_{2}$ influx (a better indicator for biological activities) is around $1.0(0.9-1.06)$ in various ecosystems (Seibt et al., 2004; Angert et al., 2012; Ishidoya et al., 2013). Since most soil respiration measurements have been conducted at the soil surface as $\mathrm{CO}_{2}$ efflux, we do not differentiate soil respiration from soil surface $\mathrm{CO}_{2}$ efflux and use the two terms loosely and interchangeably in this review. Previous studies have reviewed soil respiration measuring and modeling issues and discussed associated problems and challenges (Raich and Potter, 1995; Hanson et al., 2000; Rustad et al., 2001; Davidson et al., 2002a; Pendall et al., 2004; Hibbard et al., 2005; Ryan and Law, 2005). In this paper, we focus on some overlooked issues in measuring and modeling global Rs, such as measuring Rs on slope soils and estimating global annual Rs flux with empirical models, and further discuss the role of Rs in global carbon budgets based on the modeling results.

\section{Components of soil respiration (Rs)}

\subsection{Soil heterotrophic respiration $(R h)$}

Rh refers to the decomposition of dead soil organic matter (SOM) by soil microbes. The two main groups of these decomposers are bacteria and fungi, and they are involved in both aerobic and anaerobic degradation of organic matter. These microbes produce extracellular enzymes to convert polymeric compounds, such as cellulose, hemicellulose, and lignin, in the SOM into smaller molecules that can be further assimilated inside the microbial cells (Romaní et al., 2006). Fungi are more efficient than bacteria in the degradation of highly recalcitrant organic matter because they can produce a wider range of extracellular enzymes than bacteria (Szafranek-Nakonieczna and Stêpniewska, 2014). Although actinomycetes were found to be able to degrade lignin (Benner et al., 1984), it is generally believed that fungi decompose most of the large molecule compounds, and bacteria mainly decompose polysaccharides and polymeric compounds following the decomposition by fungi (Romaní et al., 2006). Some polymer carbohydrates can be degraded by both aerobic and anaerobic microbes, but a complete degradation of lignin requires aerobic microbes.

The decomposition of soil organic matter starts with physical and biophysical processes that break down large pieces of organic matter into smaller ones, which is followed by the biochemical transformation of complex organic molecules into simpler organic and inorganic molecules (Fig. 1). It is well known that soil organic matter exists in soil as bulk complexes. A very small portion of the SOM, such as amino acids, glucose, and fatty acids, is soluble and membrane-permeable. These SOM molecules can directly penetrate cell walls and membranes and be oxidized in the mitochondria or cytosol. Most of the SOM in soil is made of larger molecules such as starch, cellulose, lignin, protein, and lipids, which cannot penetrate microbial cell walls and membranes. Thus, these large molecules must be biochemically broken down into membranepenetrable carbon (MPC) molecules before they can be used by soil microbes.

First, soil animals, like mites and earthworms, break down the complicated bulk SOM into small pieces through various activities such as movement, chewing, or digestion. Freezing and melting of the water in bulk soils can also facilitate the breakdown of large pieces of SOM. Then, the biochemical breakdown of SOM starts with the fine particles, including carbohydrates, proteins, and lipids. The biochemical breakdown involves various extracellular enzymes for breaking specific chemical bonds (Vandermeer, 2011). For example, proteases are used for degrading proteins to amino acids, while lipases can break down lipids to fatty acids (Whiteley and Lee, 2006). Large molecules of carbohydrates are usually degraded to random chains and then broken down to MPC units from the nonreducing end of the molecular chain by cutting specific bonds, such as the $\beta-1,4$ bond in cellulose (Berg and Laskowski, 2005; Wilson, 2011). The resulting small units (the MPCs), such as monosaccharides and disaccharides, can be transported into microbial cells by diffusion, osmosis, or phagocytosis (Sauer et al., 1994). Fungi are able to spread their hyphae through the gaps between or inside 


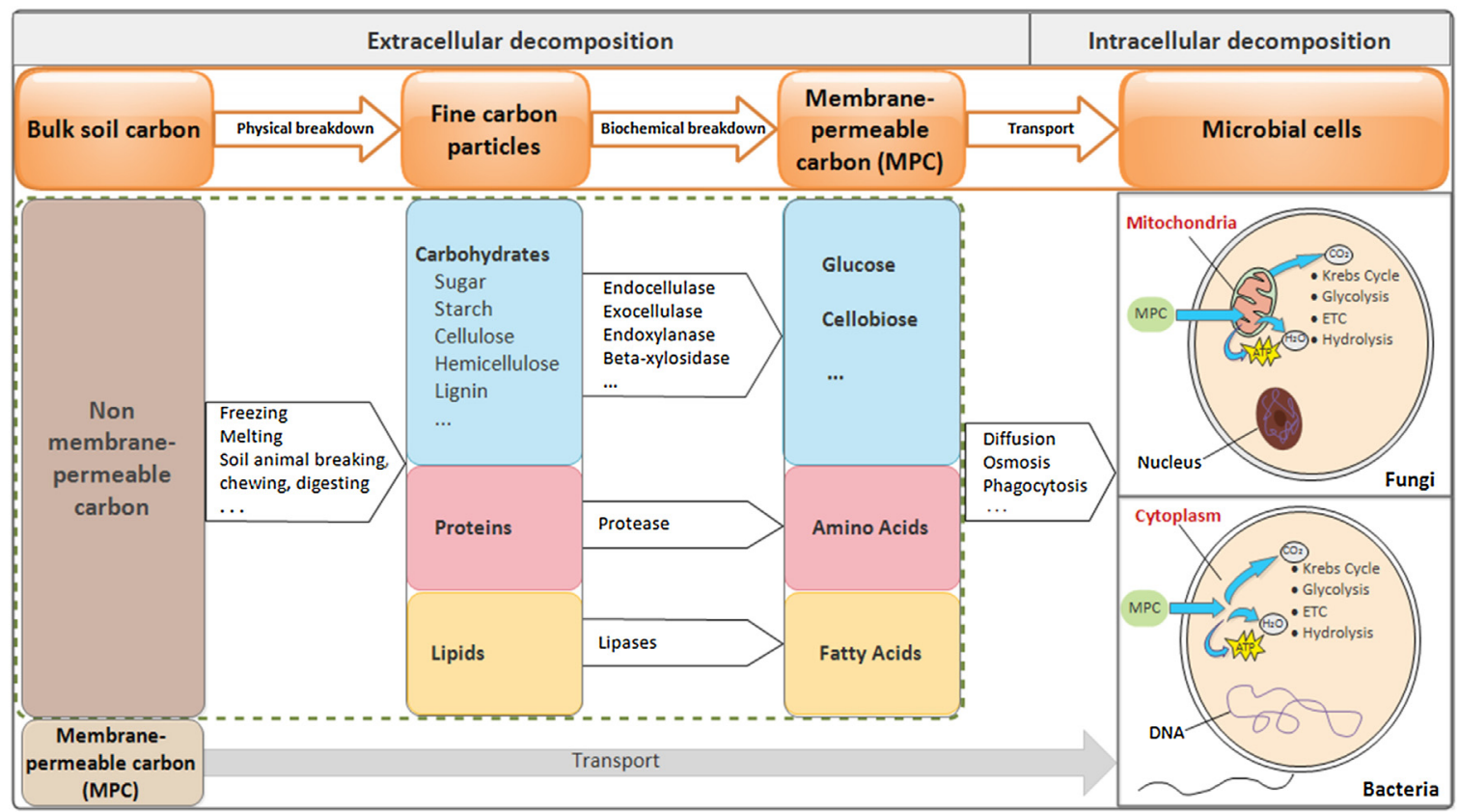

Fig. 1. Microbial decomposition of soil organic carbon.

organic matter over a long distance, which allows them to more easily access the organic matter and secrete extracellular enzymes to break down fine carbon particles. Unlike fungi, bacteria usually work as a group to break down the fine particles due to the limited enzymes each bacterial species produces. Finally, the MPCs are further broken down inside the microbial cells by intracellular enzymes in the mitochondria for fungi or the cytosol for bacteria and Archaea. Through cellular respiration, microbes break down the substrate carbon molecules and capture energy for biosynthesis and nutrient transport. Many biochemical processes, such as the Krebs cycle, glycolysis, the electron transport chain, and hydrolysis, are involved in the metabolism of carbon, with $\mathrm{CO}_{2}$ released as a final product of the processes.

\subsection{Root respiration $(R r)$}

Root respiration is a primary contributor to soil $\mathrm{CO}_{2}$ production, and hence a major factor influencing soil respiration (Raich and Tufekciogul, 2000). Root respiration includes all respiratory processes occurring in the rhizosphere according to the definition of Wiant (1967), who stated that "root respiration includes all respiration derived from organic compounds originating in plants, including the respiration of living root tissue, the respiration of symbiotic mycorrhizal fungi and associated microorganisms, and the decomposing organisms operating on root exudates and recent dead root tissues in the rhizosphere." Apparently, this definition of $\mathrm{Rr}$ is based on root functions rather than trophic levels, such as autotrophic versus heterotrophic respiration. This way of defining $\mathrm{Rr}$ has advantages in field measurements of $\mathrm{Rr}$, such as the widelyused trench method, though the Rr includes some heterotrophic respiration from the rhizosphere.

The root contribution (RC), which is the ratio of root respiration to soil respiration, varies dramatically between different ecosystems. Hanson et al. (2000) reviewed Rs partitioning methods in different biomes and ecosystems and found that the mean RC to total respiration was $45.8 \%$ and $60.4 \%$, respectively, in forest and non-forest ecosystems, but the RC varied from $10 \%$ to $90 \%$ in different studies. Subke et al. (2006) updated the database of Hanson et al. (2000) and found the RC was of $2-97 \%$ in coniferous forests, $4-73 \%$ in deciduous forests, $10-75 \%$ in grasslands, $14-73 \%$ in croplands, and $53-75 \%$ in shrublands. The RC also demonstrated a large variability within the same ecosystem due to the high spatial variation of roots and their respiration (Bond-Lamberty et al., 2004). Separating $\mathrm{Rr}$ from bulk soil respiration is a task mired with many technical challenges, though various methods have been attempted, including root exclusion, root excision, isotope, and indirect methods (Subke et al., 2006). Subke et al. (2006) did a comprehensive review on the topic and concluded that these methods generally showed good agreement, though numerous assumptions of different methods might compromise the results.

\subsection{Soil fauna respiration ( $\mathrm{Rf}$ ) and non-biological $\mathrm{CO}_{2}$ production (Rn)}

Soil fauna respiration (Rf) refers to the $\mathrm{CO}_{2}$ produced by soil animals through metabolic processes. The Rf, in general, accounts for less than $5 \%$ of the total soil respiration (Petersen and Luxton, 1982). However, in some ecosystems Rf can account for up to $10 \%$ of Rs (Sorensen et al., 2006). The non-biological $\mathrm{CO}_{2}$ production $(\mathrm{Rn})$ is the $\mathrm{CO}_{2}$ emissions at soil surface coming from physical and/or chemical processes in the soil. The physical production of $\mathrm{CO}_{2}$ is rare in normal conditions and generally occurs when soil porosity is altered by rainstorms (Tang et al., 2003), water table fluctuation, soil compression, or wind (Xu et al., 2004a). The chemical production or absorption of $\mathrm{CO}_{2}$ in soil refers to pedochemical and geological processes, such as geothermal and volcanic $\mathrm{CO}_{2}$ degassing (Werner and Brantley, 2003), photochemical degradation of litter (Austin and Vivanco, 2006), and $\mathrm{CO}_{2}$ absorption by alkaline soils (Xie et al., 2009). Under normal conditions, the nonbiological production of $\mathrm{CO}_{2}$ is negligible, but it could be significant in some special ecosystems (Rey, 2015).

\section{Factors affecting Rs}

\subsection{Soil organic carbon (SOC) quantity, quality, and availability}

Rs is ultimately determined by the quantity, quality, and availability of SOC, which are the major substrates of Rh. In the same 
ecosystem, Rh is positively correlated with soil organic carbon content because more $C$ provides more sources and more reaction sites for microbial decomposition (Wang et al., 2013). In addition to the amount of $\mathrm{C}$, soil $\mathrm{C}$ quality is also important in determining $\mathrm{Rh}$ both physically and chemically. Larger $\mathrm{C}$ particles have smaller surface area to volume (or mass) ratios, and thus have relatively smaller surface areas for contacting microbes and enzymes. Therefore, in theory, smaller soil organic particles favor Rh. In temperate or boreal climates, soil freezing and thawing in winter and spring help break down large soil organic particles to smaller pieces. Soil animals, such as earthworms, also facilitate the breakdown of soil organic particles (Bocock, 1964; Lee and Foster, 1991; Brussaard, 1998; Jennings and Watmough, 2015). The chemical composition of soil organic C, known as soil substrate quality, is also a determinant of Rh (Rustad et al., 2000; Hartley and Ineson, 2008). Small SOC molecules, such as glucose and cellobiose, can easily penetrate microbial cell walls and membranes. Large $C$ molecules, such as starch, cellulose, and lignin, are not penetrable to cell membranes and these molecules have to be broken down to small ones before they can be used by microbes. Therefore, microbes prefer labile $C$ sources (small $C$ molecules from fresh litters) over recalcitrant $C$ sources, which are more resistant to decomposition and are usually composed of large $\mathrm{C}$ molecules. In addition, $\mathrm{Rh}$ is also affected by the availability of organic C in soils (Ryan and Law, 2005). If organic $\mathrm{C}$ is absorbed or protected by soil particles, it is not available to microbes, making it very difficult to decompose even though the $C$ molecules are small. Therefore, recalcitrant soil $\mathrm{C}$ is not necessarily composed of large $\mathrm{C}$ molecules.

\subsection{Soil oxygen content}

Under aerobic conditions, molecular oxygen is an ideal terminal electron acceptor in root respiration and soil microbial decomposition. Oxygen supply is critical to ATP synthesis and $\mathrm{CO}_{2}$ production in the respiration processes. Calhoun et al.(1993) found that oxygen supply could change the efficiency of the electron transport chain by the use of different types of ubiquinol oxidase in prokaryotes. Under highly aerobic conditions, cells used an oxidase with a low affinity for oxygen, which could transport two protons per electron. When the oxygen level was reduced, they switched to an oxidase that transferred only one proton per electron, but had a high affinity for oxygen. When soil oxygen content decreases to low levels, the metabolic pathway changes from aerobic respiration to anaerobic fermentation and the products change from $\mathrm{CO}_{2}$ to $\mathrm{CH}_{4}$ (Bridgham and Richardson, 1992; Kane et al., 2013; Fan et al., 2014). Therefore, soil $\mathrm{CO}_{2}$ efflux decreases dramatically when soils are flooded, such as in wetlands (Krauss et al., 2012; Liu and Xu, 2015).

\subsection{Soil enzymes and microbes}

All of the biochemical processes involved in the breakdown of SOC require enzymes to catalyze the chemical reactions. Major enzymes in soils include amylase, $\beta$-glucosidase, cellulase, chitinase, dehydrogenase, phosphatase, protease, and urease and are produced by various microbes (Dick and Tabatabai, 1984; Gupta et al., 1993; Makoi and Ndakidemi, 2008). Although new DNA sequencing technologies have made it possible to investigate microbial community composition (Torsvik and Øvreås, 2002; Cong et al., 2015; Hartmann et al., 2015; Pitombo et al., 2015), we have limited knowledge of the details of soil enzymes, such as their amounts, types, distribution, and efficiency, and little is known of individual microbial species and the corresponding enzyme(s) produced. The importance of soil enzymes to ecosystem functions, including soil respiration, has been reviewed by Makoi and Ndakidemi (2008). Soil microbial communities and activities are regulated by climate, oxygen supply, nutrient levels, $\mathrm{pH}$, and sub- strate availability (Zogg et al., 1997; Yao et al., 2000; Barnard et al., 2014; Zhalnina et al., 2015). Given the fast propagation of microbes, microbial regulation of Rs is mainly conducted through the constraints of the above biotic and abiotic factors on microbial communities.

\subsection{Climate}

As with many other biochemical reactions, soil respiration is temperature dependent. When the soil temperature is below $0^{\circ} \mathrm{C}$, Rs is very low because of the weak metabolic rate of the root and microbes. Soil microbial activity has been reported at temperatures below $-10^{\circ} \mathrm{C}$ (Schroeter et al., 1994; Vorobyova et al., 1997; Rivkina et al., 2000). Soil respiration usually increases nonlinearly with the increase of soil temperature. The temperature sensitivity of Rs has been commonly indicated by $\mathrm{Q}_{10}$, which is the rate that Rs increases with every $10^{\circ} \mathrm{C}$ increase in soil temperature (Xu and Qi, 2001a). The $\mathrm{Q}_{10}$ determined by field measurements of Rs and temperature is known as the apparent $\mathrm{Q}_{10}$, which is attributed to many biotic and abiotic factors (Davidson and Janssens, 2006). Therefore, the $\mathrm{Q}_{10}$ reported in the literature varies surprisingly from about 1 up to 237, (Xu and Qi, 2001a; Kirschbaum, 1995; Mikan et al., 2002) with most $\mathrm{Q}_{10}$ values between 1.5 and 3.0 (Raich and Schlesinger, 1992; Winkler et al., 1996; Kätterer et al., 1998; Zhou et al., 2009).

Many high $\mathrm{Q}_{10}$ values reported in previous studies were affected by non-temperature factors, such as soil moisture and vegetation growth. Unfortunately, most of the available data for Rs were obtained through field in situ measurements, which are inevitably confounded with non-temperature factors. Therefore, using the apparent $\mathrm{Q}_{10}$ value may overestimate or underestimate the temperature effect on global Rs, and thus the ecosystem feedback to future global warming. For example, Xu and Qi (2001b) found that the confounding effect of soil temperature and moisture on Rs significantly reduced the $\mathrm{Q}_{10}$ in hot and dry summers in California forests. In this case, the soil moisture blocked the temperature effect on Rs, making the Rs insensitive to temperature change (Xu and Qi, 2001b; Wang et al., 2014a). In addition, root respiration is particularly responsive to increases in temperature, showing a $Q_{10}$ as high as 4.6 (Boone et al., 1998).

Soil moisture can affect soil respiration both directly and indirectly. Soil respiration is low in dry conditions and increases to a maximum at an intermediate moisture level until it begins to decrease when moisture content excludes oxygen. Soil moisture affects the diffusion of soluble substrates at low water content and the diffusion of oxygen at high water content, both of which can limit soil microbial respiration (Davidson et al., 2006). Microbial activity depends on soil moisture and reaches maximum levels at water contents where the limiting effects of substrate diffusion and $\mathrm{O}_{2}$ supply are equal (Skopp et al., 1990). Moreover, seasonal variation in soil moisture often couples with temperature effects on soil respiration (Xu and Qi, 2001b). In short, soil moisture affects Rs through: (1) reducing carbon mobility and availability; and (2) reducing microbial activities and thus decreasing enzyme production and mobility (Barnard et al., 2014). In addition, the hydrolytic process to break down the glycosidic bond in polysaccharides needs water molecules as reactants in both extracellular and intracellular decompositions.

\subsection{Vegetation and other factors}

Vegetation affects Rs mainly through its impacts on root respiration $(\mathrm{Rr})$, litter production and root exudation. Vegetation can also affect Rs through its aboveground canopy photosynthesis, which is the source of root exudates (Högberg et al., 2001; Tang et al., 2005a; Mencuccini and Hölttä, 2010). Rhizosphere respiration (Rz) is highly dependent on the carbohydrate supply from photosynthe- 
sis, which also depends on plant physiological and morphological factors in addition to climate. Therefore, $\mathrm{Rz}$ is probably the most dynamic component of Rs due to the rapid changes in climate and vegetation growth. Root maintenance and growth respirations are also regulated by aboveground photosynthesis, but they may take effect at a slower pace than Rz. For these reasons, Rz should be separated from root maintenance and growth respiration and considered separately in ecosystem models by directly coupling with photosynthetic processes, mainly NPP allocation. Thus, in situ measurements of Rz are critical to understanding the aboveground and belowground interactions of the ecosystem carbon cycle and improving the accuracy of modeling Rs. Isotopic methods have been used for measuring $\mathrm{Rz}$ in various ecosystems, though further improvements are needed to increase the accuracy and reliability of the technology (Cheng, 1996; Rochette and Flanagan, 1997; Kuzyakov and Cheng, 2001; Moyes et al., 2010; Werth and Kuzyakov, 2010).

Vegetation can also affect Rs through litter fall (both aboveground and root litter), which is the main source of SOC. At a global scale, annual litter production is highly correlated with SOC and Rs (Raich and Tufekciogul, 2000; Davidson et al., 2002a; Sayer et al., 2007; Han et al., 2015). In addition to litter production, the species composition of vegetation may alter litter quality and thus Rs (Hättenschwiler et al., 2005; Chiang et al., 2014). For example, Harmon et al. (2009) found that the long-term average or integrated decomposition rates of nine different litter types ranged from 0.017 to 4.653 year $^{-1}$, with an average of 0.353 year $^{-1}$. Different vegetation types may feature different SOCs in terms of the amount and quality and thus sustain different microbial communities (Wang et al., 2014b). Vegetation also alters microclimate, such as soil temperature and moisture (Xu et al., 1997; Xu et al., 2004b), and thus affects Rs indirectly.

Human activities, such as land use change, cultivation, cropping, fertilization, and irrigation significantly affect soil respiration. When soils are disturbed through cultivation, their organic matter content declines (Schlesinger and Andrews, 2000). This is because cultivation improves soil aeration and moisture, which leads to greater rates of soil respiration. In addition, the input of fresh plant debris to soils decreases when native vegetation is converted to agriculture. Cultivation also disrupts soil aggregates, exposing stable, adsorbed organic matter to decomposition (Elliott, 1986; Six et al., 1998). Other factors, such as soil properties, fire (Wüthrich et al., 2002), and pollution (Ilangovan and Vivekanandan, 1992; Liang et al., 2013) can also affect Rs through their impacts on soil carbon availability, nutrient supply, microclimate and microbial activities (Boshoff et al., 2014).

\section{Soil respiration measurements}

\subsection{Methods and challenges}

The early measurements of Rs can be traced back to the period between 1900 and 1930, when Rs was used as a soil fertility index (Darbishire and Russell, 1907; Truog, 1915; Gainey, 1919; Waksman and Starkey, 1924; Lundegårdh, 1927; Smith and Brown, 1931). The chamber method has been widely used for Rs measurements. During the measurement, a chamber is placed on the soil surface and the $\mathrm{CO}_{2}$ molecules emitted from the soil are trapped inside the chamber. The early measurements of Rs used the chemical absorption (CA) method, in which the respired $\mathrm{CO}_{2}$ molecules were absorbed by alkali solutions and determined by titration (Norman et al., 1992). With the advance of the infrared gas analyzer (IRGA) in the 1970s, the accuracy of Rs measurements has significantly improved (Norman et al., 1992; Pongracic et al., 1997; Davidson et al., 2002a). Some studies have also used gas chro- matography (GC) to analyze the $\mathrm{CO}_{2}$ concentration, but mostly for simultaneous measurements of multiple greenhouse gas (GHG) species, such as $\mathrm{CO}_{2}, \mathrm{CH}_{4}$, and $\mathrm{N}_{2} \mathrm{O}$ (Ball et al., 1999; von Arnold et al., 2005; Abbasi and Müller, 2011). Currently, most people use the dynamic chamber system to measure $\mathrm{CO}_{2}$ concentration buildup inside the chamber with an IRGA and Rs flux is calculated based on the rate of $\mathrm{CO}_{2}$ concentration change with time.

Although Rs has been studied for more than a century, measuring Rs in the field is still filled with many challenges. The CA method (alkali solution or soda lime) usually underestimates Rs under high respiration rates due to the diffusion barriers of $\mathrm{CO}_{2}$ molecules at the absorption surface and overestimates Rs under low respiration rates due to the strong $\mathrm{CO}_{2}$ absorption effect on the $\mathrm{CO}_{2}$ diffusion gradient (Norman et al., 1997; Rochette et al., 1997; Yim et al., 2002; Wayson et al., 2006). Recent studies also found that the CA method could measure Rs comparably with the IRGA method if properly implemented and corrected (Grogan, 1998; Keith and Wong, 2006). The $\mathrm{CO}_{2}$ gradient method has also been adopted by some researchers because of its minimal disturbance during the measurements (De Jong and Schappert, 1972; Tang et al., 2005b; Pingintha et al., 2010), but this method also has limitations, such as the empirically determined $\mathrm{CO}_{2}$ diffusivity in soils and the disturbances to soils introduced by the initial installation of the $\mathrm{CO}_{2}$ sensors. There have been a number of studies and reviews comparing different methods to measure Rs and discussing the strengths and limitations of each method (Hanson et al., 2000; Davidson et al., 2002b; Hibbard et al., 2005; Pendall et al., 2004; Ryan and Law, 2005). Here, we want to discuss an overlooked issue on measuring Rs, that of measuring Rs on slope soils.

Although thousands of studies on Rs measurements have been published in the literature and many were conducted on slope soils, few studies have reported the details of chamber or soil collar installation (e.g. orientation) and corrections to the measured Rs fluxes. To avoid the slope effect, many researchers choose relatively flat areas for setting up their Rs measurements. This is particularly true when Rs measurements are taken at the same site with eddy covariance towers, which usually require flat terrains (IPCC, 2000). As a result, few Rs measurements have been taken on steep slopes, which means the slope soils are underrepresented in the Rs databases.

Most of the earth's land surface is not perfectly flat and a large portion of the world forests is located in mountain ranges. For scaling up purposes, Rs must be measured and reported with respect to vertically-projected areas because the earth's "true" surface area is unknown and scale-dependent. This means the soil chambers have to be vertically installed, parallel to the gravitational field. If the chamber is installed perpendicularly to the slope surface, the measured Rs flux should be converted to vertically projected-area based flux by:

$\mathrm{Fv}=\mathrm{F} / \cos \theta$

Where Fv is the vertically projected Rs flux, $\mathrm{F}$ is the Rs flux measured perpendicularly to the slope surface (the chamber area), and $\theta$ is the slope angle in degree.

Apparently, Fv is greater than F on slope soils because the collar area (a circle) becomes smaller when projected to the horizontal surface (an oval) (Fig. 3C). The difference is less than $1.5 \%$ if the slope angle is smaller than $10^{\circ}$. However, the difference between $\mathrm{Fv}$ and $\mathrm{F}$ increases rapidly with the increase of slope angle, reaching $15.5 \%$ at $30^{\circ}$ and $41.4 \%$ at $45^{\circ}$. Thus, a correction is necessary on steep slopes. The slope can be determined by measuring the height difference between the upper and lower sides of the chamber bottom. For repeatable measurements of Rs, soil collars are usually installed to avoid disturbances of soils during the measurements. The collars are often made of PVC pipe and about $4-10 \mathrm{~cm}$ in height. The collar is pushed into the soil vertically (parallel to the gravitational field) 


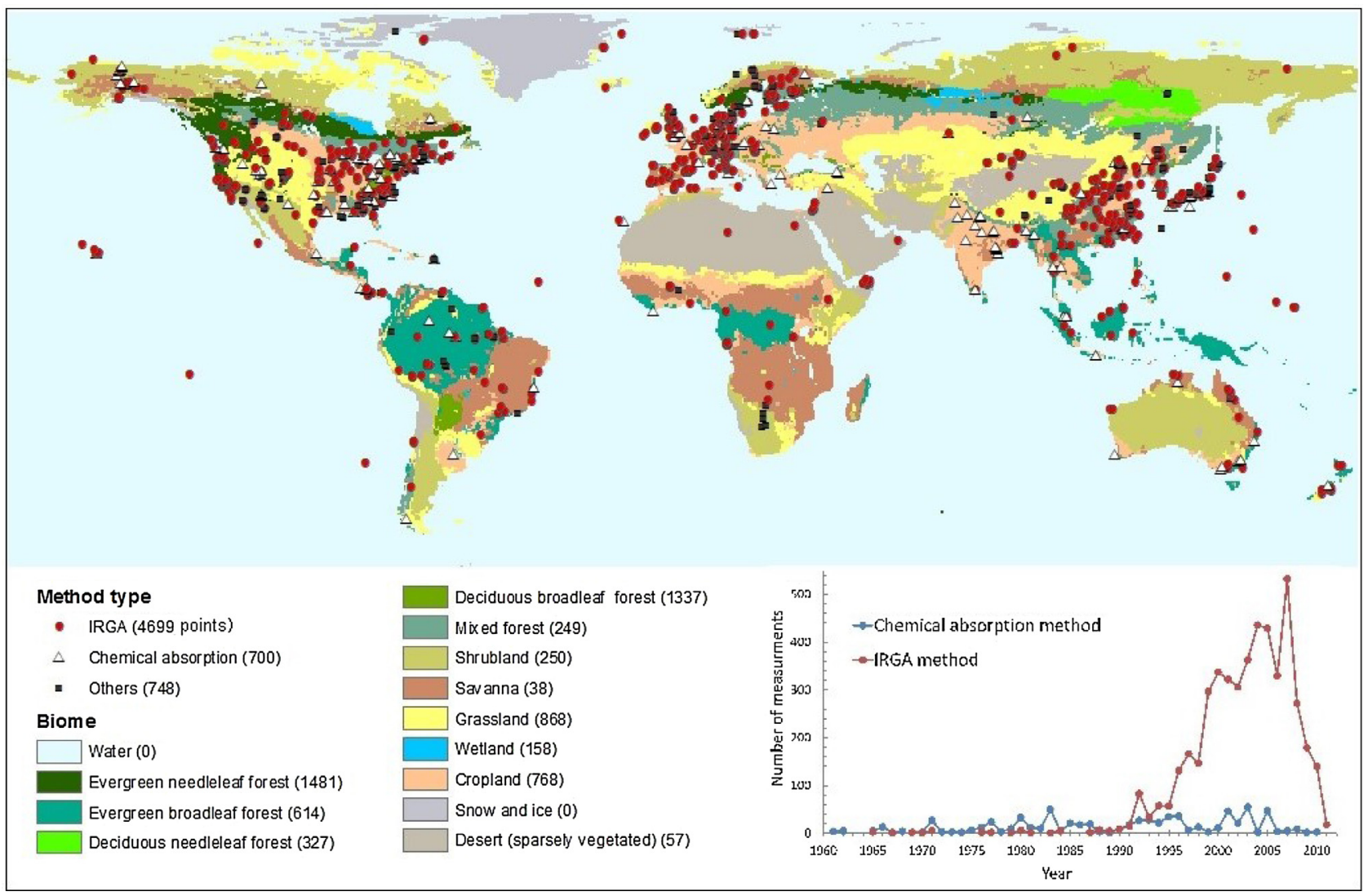

Fig. 2. The spatial and temporal distribution of soil respiration (Rs) measurements at a global scale.

with about 1-2 cm above the soil surface. In case of measuring Rs on slopes, taller collars are needed to ensure the lower side of the collar can be inserted deep enough into the soil. The vertical installation avoids having to correct the measured Rs flux and minimizes the effects of collar wall on altering soil water movement during rain events. However, there are other problems with tall soil collars.

Measuring Rs on steep slopes requires taller soil collars with the majority of the collar inserted into the soil, especially the upper-slope side of the collar (Fig. 3D). According to the molecular diffusion theory, the diffusion direction of $\mathrm{CO}_{2}$ molecules in soils should be perpendicular to the slope surface to minimize the path length and thus the diffusion resistance. When the soil collar is vertically inserted into soils, the upper-slope side of the collar wall will block the $\mathrm{CO}_{2}$ molecules moving upwards from deeper soils (Fig. 3D). As a result, the flux of Rs is underestimated by the vertical installation of the soil collar, particularly on steep slopes where tall soil collars are needed. Deep collar insertion also runs the risk of severing roots and thus underestimating Rs. The height of the soil collar also needs to increase with increasing diameter of the soil collar. To solve the problem of the collar wall blocking $\mathrm{CO}_{2}$ diffusion, we recommend that obliquely-cut soil collars (OCSC) should be adopted instead of the traditional cylindrical collars (Fig. 3E). The OCSC is fabricated by cutting one end of the collar with an angle matching the soil slope. This means the down-slope side of the collar is taller than the up-slope side (Fig. 3E). The height of the down-slope side of the soil collar can be calculated as:

$\mathrm{H}=\mathrm{Ha}+\mathrm{Hi}+\mathrm{D} * \tan \theta$

Where $\mathrm{H}$ is the height $(\mathrm{mm})$ of the down-slope side of the collar (also the height of PVC sections), Ha is the height above soil surface at the up-slope side of the collar for connecting the soil chamber (usually $10-20 \mathrm{~mm}$ ), Hi is the depth of the collar inserted into soils, usually $30-100 \mathrm{~mm}$ depending on soil texture, $\mathrm{D}$ is the diameter of the collar (mm), and $\theta$ is the angle of soil slope in degree.

For the traditional chemical absorption method, the measured Rs flux has to be converted to vertically-projected area based flux (Fig. 3B) using equation 1 if the enclosure is positioned along the slope. Since the enclosures used for this method usually cover a larger soil area than the IRGA chambers, when measuring on slopes researchers often orient the enclosures perpendicularly to slope surface to avoid deep insertion of the enclosure into soils for minimizing disturbances to the soil. In this case, corrections to the measured Rs flux to vertically-projection-area based flux are necessary, especially on steep slopes. If soil collars are used for repeatable measurements, this method has the same problem of blocking $\mathrm{CO}_{2}$ diffusion by the collar wall as discussed earlier. In this case, the extra volume introduced by the vertical installation of the collar on slope soils should be added to the total system volume.

For applying the gradient method to measure Rs on slope soils, the measured Rs fluxes also need to be corrected to the verticallyprojection-area based fluxes even though soil chambers and collars are not used for the measurements. The detailed methods depend on the sensor installation. If the $\mathrm{CO}_{2}$ sensors are installed along a profile perpendicular to the soil slope, then measured Rs flux is also perpendicular to the slope (Fig. 3A). Eq. (1) can be used to convert the measured flux to vertically-projected area based flux. If the $\mathrm{CO}_{2}$ sensors are installed along a vertical profile (parallel to the gravitational field) (Fig. 3A), then the measured Rs flux should be converted with the following equation:

$\mathrm{FV}=\mathrm{F} /(\cos \theta)^{2}$

Where Fv is the vertically projected Rs flux, $\mathrm{F}$ is the Rs flux measured with the vertical gradient of $\mathrm{CO}_{2}$ concentration, and $\theta$ is the slope angle in degree. In Fig. $3 \mathrm{~A}$, the $\mathrm{CO}_{2}$ concentration is the same at 


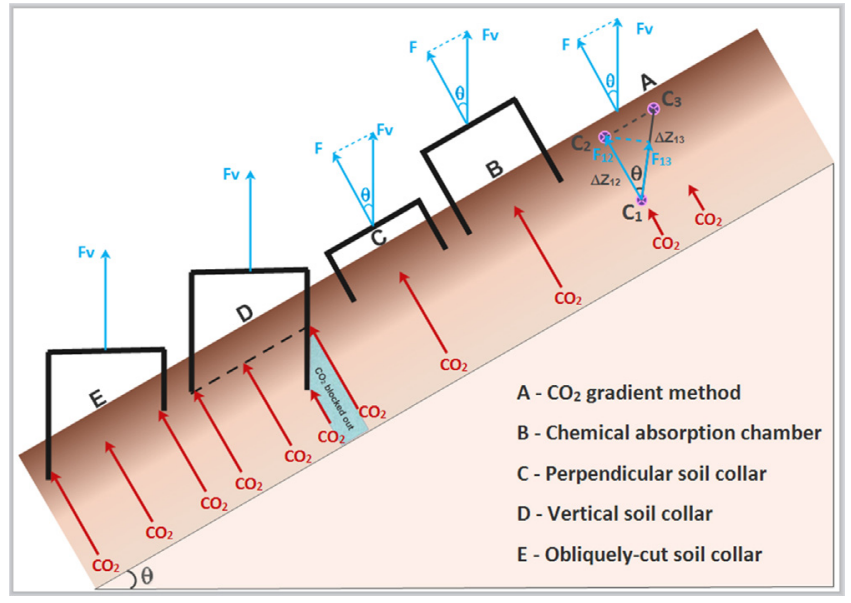

Fig. 3. Measuring soil respiration (Rs) on slope soils.

points $C_{2}$ and $C_{3}$, but the distance between $C_{1}$ and $C_{3}\left(\Delta Z_{13}\right)$ is greater than that between $C_{1}$ and $C_{2}\left(\Delta Z_{12}\right)$. This means a smaller Rs flux $\left(F_{13}\right)$ will be produced if $\Delta Z_{13}$ is used for calculating the flux. So, we first need to correct $F_{13}$ to $F_{12}$ by dividing $F_{13}$ with $\cos \theta . \mathrm{F}_{12}$ is the $\mathrm{CO}_{2}$ flux perpendicular to the slope surface and we need to further correct it to the vertically-projection-area based flux discussed earlier in equation 1. By combining the two steps together, we obtained equation 3.

\subsection{Spatial and temporal distribution of Rs measurements}

A number of studies have synthesized the measurements of Rs at global and regional scales (Raich and Schlesinger, 1992; Raich and Potter, 1995; Raich et al., 2002; Bond-Lamberty and Thomson, 2010a; Chen et al., 2014; Epule, 2015). We added three currently available Rs databases (Bond-Lamberty and Thomson, 2014; Chen et al., 2014; Epule, 2015) together and found that the total number of Rs measurements by 2011 was 6147 globally, conducted at 1557 sites, with most of the measurements conducted in North America (but a few in Mexico), Western Europe, and East Asia (Fig. 2). Few measurements were found in Africa, the Middle East, East Europe, and Australia. By biomes, most of the measurements of Rs were found in evergreen needleleaf forests (1481 measurements) and only 38 and 57 measurements for savanna and desert (sparsely vegetated) ecosystems respectively (Fig. 3 ). We also examined the methods used to take these measurements and found that $76.5 \%$ of the Rs measurements used the IRGA-based method, $11.4 \%$ used the chemical absorption method (alkali trap or soda lime), 9.7\% used gas chromatography, and $0.8 \%$ used the gradient method. Temporally, we found that most of the measurements were taken in the 1990 s and 2000s; only about $6.4 \%$ of the measurements were taken before 1990 (Fig. 2). It is noted that most of the recent measurements after 1990 were taken using the IRGA method with very few measurements using the chemical absorption method after 2006. Spatially, most of the measurements in India were taken using the chemical absorption method, mainly in croplands (Fig. 2). Longterm measurements (measurement duration $\geq 1$ year) accounts for about 70\% (4263 measurements at 1120 sites) of the total measurements in the database.

How many measurements are needed to reasonably estimate global Rs flux statistically? We calculated the coefficient of variance (CV) of the annual Rs flux for the globe and each biome (derived from the MODIS global vegetation map) using the new database. Globally, the CV of annual Rs is 0.623 ; if all of the annual Rs measurements were randomly distributed on the globe we would need a sample size of 591 and 148 (using Eq. (4)), respectively, for a relative error of $5 \%$ and $10 \%$ with a confidence level of $95 \%$.

$\mathrm{n}=(1.96 * \mathrm{CV} / \mathrm{E})^{2}$

Where $\mathrm{n}$ is the sample size, CV is the coefficient of variation of Rs, and $\mathrm{E}$ is the relative error.

Since each site may have multiple measurements (multiple locations or years), we averaged all of the measurements at each site and derived a new site-averaged database with 1120 records. If all the available annual Rs measurement sites (1120) were randomly distributed across the globe and the Rs flux had followed a normal distribution, we could achieve an accuracy of $96.4 \%$ in estimating global mean Rs flux statistically (Eq. (4)) (Table 1). Apparently, the spatial distribution of the sites is not random as discussed earlier (Fig. 3). The actual sampling accuracy for each biome is different due to the non-homogeneous variation and sample size among biomes (Table 1). The highest sampling accuracy (1.0-E) was $93.7 \%$ in evergreen needleleaf forests and deciduous broadleaf forests, followed by evergreen broadleaf forests and mixed forests of $91.8 \%$ (Table 1). The lowest accuracy was found in deserts (sparely vegetated), savannas, and shrublands, with $65.3 \%, 66.8 \%$, and $66.6 \%$, respectively (Table 1 ). Considering the uneven distribution of the sites among biomes and the differences between mean Rs and area of the biomes, we used a weight factor (biome area $\times$ biome mean Rs) to calculate the overall estimation accuracy. The overall sampling accuracy of the 1120 sites was only $81.0 \%$, yielding an estimation error of about $17.9 \mathrm{PgC} / \mathrm{yr}$. Therefore, to improve the estimation accuracy of global annual Rs flux we need to increase the sample size, especially in deserts, savannas, and shrublands where the sample size is under 50 . The global net ecosystem productivity (NEP) is currently about 2.4 PgC/yr (Le Quéré et al., 2015) which is only about $3 \%$ of the global annual Rs flux. Apparently, the global Rs flux estimated with the statistical methods is not accurate enough for estimating the global NEP even though thousands of Rs measurements have been conducted over the globe. The problem is not because we do not have enough measurements, but because the measurements are not evenly distributed across the globe.

Acknowledging that the different methods used for measuring Rs may impact the estimation of global Rs flux, we extracted all the Rs records in the database measured by IRGA or GC or the $\mathrm{CO}_{2}$ gradient (also using IRGA analyzer) method and came up with a new database of 3686 measurements at 969 sites. We recalculated the mean Rs flux and its CV in each biome and found that the global mean (site-based) Rs flux increased slightly from $0.817 \mathrm{kgC} / \mathrm{m}^{2} / \mathrm{yr}$ to $0.845 \mathrm{kgC} / \mathrm{m}^{2} / \mathrm{yr}$, suggesting that the impact of the chemical absorption (CA) method on estimating global mean Rs is minor. Previous studies showed that the CA method generally underestimates the Rs under high respiration rates and overestimates Rs under low respiration rates (Ewel et al., 1987; Rochette et al., 1992; Nay et al., 1994; Bekku et al., 1997; Norman et al., 1997; Knoepp and Vose, 2002). Our results suggest that the errors of the CA method might cancel out in estimating global mean Rs flux. Therefore, the Rs data measured with the CA method are valuable in estimating global Rs flux using the traditional statistic approach, but may bias the regional estimation of Rs flux.

With the rapidly increasing use of IRGA analyzers, we expect the global Rs data will continue to increase in both quantity and quality in the future. However, the uneven distribution sampling problem will remain if international collaborations on climate change and carbon cycling do not significantly improve in the future. As we have seen in Fig. 2, most of the gaps of Rs measurements are located in the least developed countries, such as Africa, Southeast Asia, the Middle East and Mongolia, and in remote areas and ecosystems with poor access. Financial and technical assistance from the developed world or international organizations are sorely needed to support more measurements in these areas for filling the data 
Table 1

Statistics of global soil respiration (Rs) measurements by biomes.

\begin{tabular}{|c|c|c|c|c|c|c|c|c|c|}
\hline \multirow[t]{3}{*}{ Biome } & \multirow{3}{*}{$\begin{array}{l}\text { Area } \\
10^{6} \mathrm{~km}^{2}\end{array}$} & \multicolumn{4}{|l|}{ All sites } & \multicolumn{4}{|c|}{ IRGA or GC based sites } \\
\hline & & \multirow[t]{2}{*}{ Number of sites } & \multicolumn{3}{|l|}{ Soil respiration flux } & \multirow[t]{2}{*}{ Number of sites } & \multicolumn{3}{|l|}{ Soil respiration flux } \\
\hline & & & Mean $\left(\mathrm{kgC} / \mathrm{m}^{2} / \mathrm{yr}\right)$ & $\mathrm{CV}$ & Accuracy (\%) & & Mean $\left(\mathrm{kgC} / \mathrm{m}^{2} / \mathrm{yr}\right)$ & $\mathrm{CV}$ & Accuracy (\%) \\
\hline 1. Evergreen needleleaf forest & 4.07 & 243 & 0.732 & 0.500 & 93.72 & 203 & 0.742 & 0.495 & 93.19 \\
\hline 2. Evergreen broadleaf forest & 13.72 & 170 & 1.231 & 0.548 & 91.76 & 150 & 1.287 & 0.530 & 91.52 \\
\hline 3. Deciduous needleleaf forest & 1.67 & 81 & 0.727 & 0.482 & 89.50 & 78 & 0.749 & 0.451 & 89.98 \\
\hline 4. Deciduous broadleaf forest & 1.41 & 241 & 0.821 & 0.495 & 93.75 & 208 & 0.852 & 0.477 & 93.51 \\
\hline 5. Mixed forest & 8.99 & 56 & 0.797 & 0.313 & 91.80 & 56 & 0.797 & 0.313 & 91.80 \\
\hline 6. Shrubland & 20.50 & 41 & 0.482 & 1.092 & 66.56 & 32 & 0.534 & 1.052 & 63.56 \\
\hline 7. Savanna & 20.40 & 13 & 0.910 & 0.610 & 66.85 & 11 & 0.796 & 0.623 & 63.19 \\
\hline 8. Grassland & 18.26 & 143 & 0.813 & 0.718 & 88.24 & 125 & 0.841 & 0.685 & 87.99 \\
\hline 9. Wetland & 1.22 & 30 & 0.446 & 0.735 & 73.70 & 24 & 0.425 & 0.722 & 71.09 \\
\hline 10. Cropland & 20.55 & 86 & 0.691 & 0.613 & 87.04 & 68 & 0.704 & 0.626 & 85.12 \\
\hline 11. Snow and ice & 2.92 & 0 & & & & 0 & & & \\
\hline 12. Desert (sparsely vegetated) & 18.57 & 16 & 0.366 & 0.707 & 65.34 & 14 & 0.390 & 0.691 & 63.82 \\
\hline 13. Water & 2.10 & 0 & & & & 0 & & & \\
\hline Total & 134.38 & 1120 & 0.817 & 0.623 & 96.35 & 969 & 0.845 & 0.609 & 96.16 \\
\hline
\end{tabular}

gaps. New technologies, such as smart soil chambers, robots, and drones can also be explored to facilitate Rs measurement in harsh and difficult-to-access ecosystems.

\section{Estimation of global Rs flux}

\subsection{Simple statistic method}

In a review of global carbon balance in terrestrial detritus, Schlesinger (1977) estimated the global Rs annual flux to be 75 $\mathrm{PgC} / \mathrm{yr}$ by assuming Rs flux is twice that of litter fall (above and belowground litter fall). Houghton and Woodwell (1989) estimated that the global Rs was about $50 \mathrm{PgC} / \mathrm{yr}$. By compiling the Rs flux data published in the literature, Raich and Schlesinger (1992) established a global Rs annual flux database of 171 measurements. Using the average Raich Rs flux of 13 biomes and multiplying the biome area from different sources, they found that the global Rs flux was $68 \pm 4 \mathrm{PgC} / \mathrm{yr}$, of which root respiration contributed about $26 \%$ (Raich and Schlesinger, 1992). It should be noted that the range of $\pm 4 \mathrm{PgC} / \mathrm{yr}$ here is not the standard deviation of the Rs samples nor the $95 \%$ confidence interval. It is the standard deviation of global Rs annual fluxes estimated based on different maps of vegetation biomes (Raich and Schlesinger, 1992). Using our new database and the MODIS vegetation map (Table 1), we estimated the global annual Rs flux to be 94.3 PgC/yr with an estimation error of $17.9 \mathrm{PgC} / \mathrm{yr}$ at a $95 \%$ confidence level. Our estimate, based on the statistics of the global Rs database, is very close to the recent estimates of $91 \mathrm{PgC} / \mathrm{yr}$ by Hashimoto et al. (2015) and $98 \mathrm{PgC} / \mathrm{yr}$ by Bond-Lamberty and Thomson (2010b). By comparing with our most current database on Rs, we found that the standard deviation of annual Rs was much lower in Raich and Schlesinger (1992) than that of the current database. Sample size and the spatial distribution of the measurements may have contributed to the difference. As discussed earlier, the high uncertainties associated with the statistical method have limited the applications of the results to global carbon accounting, such as the estimation of global NEP.

\subsection{Empirical models}

Recognizing the uneven distribution of global Rs measurements and the limitations of the statistical approach, people have started developing regression models as alternatives to improve the estimate of global Rs flux. Raich and Potter (1995) developed a global database with 977 records of monthly Rs fluxes measured from 1963 to 1991 (including data measured with the chemical absorption method). By extracting the corresponding monthly air temperature and precipitation from a $0.5^{\circ} \times 0.5^{\circ} \mathrm{cli}-$ mate database (Legates and Willmott, 1990a,b), they developed a nonlinear regression model (Eq. (5)) and estimated that the global Rs flux was $76.5 \mathrm{PgC} / \mathrm{yr}$.

$\mathrm{SR}=\mathrm{F} \times \mathrm{e}^{(\mathrm{Q} \times \mathrm{T})} \times(\mathrm{P} /(\mathrm{K}+\mathrm{P}))$

Where SR ( $\mathrm{gC} / \mathrm{m}^{2} /$ day) is the soil $\mathrm{CO}_{2}$ flux, $\mathrm{F}\left(\mathrm{gC} / \mathrm{m}^{2} /\right.$ day), $\mathrm{Q}\left({ }^{\circ} \mathrm{C}^{-1}\right)$, and $\mathrm{K}(\mathrm{cm} / \mathrm{month})$ are coefficients, $\mathrm{T}\left({ }^{\circ} \mathrm{C}\right)$ is the mean monthly air temperature, and $\mathrm{P}(\mathrm{cm})$ is the mean monthly precipitation.

Later, Raich et al. (2002) updated their database to 335 records measured mostly by the IRGA technique from 1968 to 2000 (dropping most of the chemical absorption measurements) and refitted the model to get an estimate of global annual Rs of $80.4 \mathrm{PgC} / \mathrm{yr}$ (1980-1994 average). The authors did not give the confidence interval of their estimations in either study. Using the mean square error (MSE) (0.1-6.2 ( $\mathrm{gC} / \mathrm{m}^{2} /$ day $\left.)^{2}\right)$ reported in the second study, we took the lower end of the MSE range $\left(0.1\left(\mathrm{gC} / \mathrm{m}^{2} / \text { day }\right)^{2}\right)$ and found the standard deviation of their global annual Rs flux was $16.9 \mathrm{PgC} / \mathrm{yr}$, giving a 95\% confidence interval of $80.4 \pm 33.2$ $\mathrm{PgC} / \mathrm{yr}(1.96 \times 16.9=33.2)$. By compiling a more comprehensive database of annual Rs flux (1434 measurements from 439 studies), Bond-Lamberty and Thomson (2010b) developed a linear regression model with annual temperature, precipitation, temperature anomalies and precipitation anomalies as independent variables. Using this model, they estimated the global Rs flux was $98 \mathrm{PgC} / \mathrm{yr}$ with a standard deviation of $12 \mathrm{PgC} / \mathrm{yr}$ in 2008 and also found that the global Rs significantly increased from 1989 to 2008 . So, the $95 \%$ confidence interval of their estimation is $98 \pm 23.5 \mathrm{PgC} / \mathrm{yr}$. More recently, Hashimoto et al. (2015) improved the Raich and Potter model by letting the temperature sensitivity $\left(Q_{10}\right)$ linearly decrease with the increase in temperature and by considering the effect of previous-month precipitation on Rs in addition to the current month. By using the same database (excluding agricultural sites) as used by Bond-Lamberty and Thomson (2010b) and new climate data to parameterize the model, Hashimoto et al. (2015) estimated that the global mean annual Rs was $91 \pm 4 \mathrm{PgC} / \mathrm{yr}$ (1965-2012 average, $95 \%$ confidence interval). This is, thus far, the best estimation of global Rs flux with an estimation error of $4 \mathrm{PgC} / \mathrm{yr}$, which is still too "poor" to independently estimate global NEP (2.4 PgC/yr). At the global scale, croplands, on average, have lower Rs than forests and grasslands. Using our newly integrated database on Rs we found that the global average Rs of cropland is $0.704 \mathrm{kgC} / \mathrm{m}^{2} / \mathrm{yr}$ which is much lower than that of forests of $0.907 \mathrm{kgC} / \mathrm{m}^{2} / \mathrm{yr}$ and also lower than that of grassland of $0.841 \mathrm{kgC} / \mathrm{m}^{2} / \mathrm{yr}$. The lower Rs in croplands is due mainly to lower carbon inputs to soils by removing aboveground biomass during harvesting. Hashimoto et al. (2015) 
excluded croplands from the Rs database when they parameterized their model. Thus, the global annual Rs flux estimated by Hashimoto et al. (2015) is the "potential" Rs which should be greater than the true Rs flux.

These empirical models have advantages over the pure statistical method by partially avoiding the sampling bias issue. Most of the regression models gave an $\mathrm{R}^{2}$ value between 0.3 and 0.6 (Raich and Potter, 1995; Raich et al., 2002; Hashimoto et al., 2015), which means a lot of variances in the Rs flux were not explained by climate and vegetation variables. These models can be further improved in many ways.

First, the database can be augmented by adding more measurements in Africa, Eastern Europe, North Asia, the Middle East, and Southeast Asia, particularly in arid and semi-arid ecosystems. Improving data quality is more important than data points. Deleting some low quality data points in the databases is necessary, such as the sites with few spatial replicates and less frequent measurements, data measured under rainy, windy, freezing, thawing, and flooding conditions, and measurements with non-IRGA based methods. Scaling up Rs measurements should start along the temporal dimension to obtain annual fluxes using non-linear regression models with soil temperature and moisture as independent variables (Xu and Qi, 2001b; Qi and Xu, 2001). Then, the site-averaged annual Rs flux can be obtained by averaging the annual Rs fluxes at individual locations over the site. On selecting new measurement sites, one has to consider the "footprints" of the site to represent the adjacent vegetation, soil, topography, and microclimate conditions for matching the remote sensing and climate data in building Rs models. In cases where multi-year Rs measurements are available, one can use the climate data of each year in building the models to increase sample size. If multi-year-averaged climate data is used, one needs to average annual Rs over the years to match the temporal scale of the climate data.

Second, building models at annual time-steps instead of at monthly steps may reduce noise and time-lag effects on Rs measurements. This is favored by the increasing use of automatic Rs systems which produce high-quality, long time-series Rs flux data. In addition, the monthly Rs fluxes are not independent, and neither are the monthly temperature and precipitation levels (Xu et al., 1997, 2004a,b).

Third, using high-resolution climate data ( $1 \mathrm{~km}$ or finer resolution) will substantially improve the modeling fitting by minimizing the scale-mismatching effect between the Rs and climate data. The half-degree climate data as used in earlier models are too coarse to match the plot-based Rs measurements.

Fourth, the Rs models can be improved by including new variables, such as SOC, leaf area index (LAI), Normalized Difference Vegetation Index (NDVI), and snow coverage, and new modeling techniques, such as spatial hierarchical modeling, data mining and machine learning techniques. For example, Chen et al. (2014) found that adding SOC to the Raich et al. model could significantly improve the model fitting. Hashimoto et al. (2015) found that adding LAI and GPP to the Rs model could reasonably increase the model performance. Other studies have also shown that NDVI was highly correlated with Rs at regional scale (Huang et al., 2013; Wu et al., 2014). Climate alone is not sufficient to model Rs because vegetation and soil conditions are also critical to Rs. It is true that climate determines vegetation distribution and growth at a global scale in the absence of disturbances. But in reality, we have seen very different vegetation and soil statuses in a similar climate due mainly to human and natural disturbances.

Finally, the model formulation can also be improved. In the current models, the precipitation effect on Rs is independent of temperature, which is not true in many cases. For example, an annual precipitation of $300 \mathrm{~mm}$ in an alpine ecosystem is enough to maintain the soil moisture moderately high because the low temperature suppresses evapotranspiration, while in low elevation areas, annual precipitation of $300 \mathrm{~mm}$ makes a semi-desert. In addition, the current models do not consider the effect of high precipitation, thus high soil moisture, on limiting Rs by reducing oxygen supply.

\subsection{Process-based models}

Process models are based on physical and ecological processes dictating ecosystem functions, including Rs. These models integrate all the major ecosystem processes, such as photosynthesis, respiration, decomposition, evapotranspiration, nutrient cycling, and phenology (Running and Hunt, 1993; Parton et al., 1993; Melillo et al., 1993). Although process-based models need observation data for initialization and parameterization, they rely on the knowledge and understanding of the interactions among different processes. Thus, the models can be generally applied to ecosystems with minimal information. Most ecosystem models and earth system models estimate heterotrophic $(\mathrm{Rh})$ and root $(\mathrm{Rr})$ respiration, but few have reported their results on $\mathrm{Rr}$. Thus, it is impossible to compare the global Rs estimates from empirical models with those from processbased models. Since Rh is the dominant component in Rs, the global Rh values estimated by the earth system models may give us some clues on Rs. Hashimoto et al. (2015) compared the Rh values of 20 earth system models and found that the variation of Rh among the models was very large, ranging from about 42 to $73 \mathrm{PgC} / \mathrm{yr}$ with a mean of $54 \mathrm{PgC} / \mathrm{yr}$. Shao et al. (2013) also assessed global Rh from 8 earth system models and found that Rh ranged from 41.3 to $71.6 \mathrm{PgC} / \mathrm{yr}$, with a mean of $60 \mathrm{PgC} / \mathrm{yr}$. By averaging the results of these two studies, we got a global mean Rh of $57 \mathrm{PgC} / \mathrm{yr}$. Given the global net ecosystem productivity (NEP) of about 2.4 PgC/yr ( La Quere et al., 2015), then we calculate a global NPP of $59.4 \mathrm{PgC} / \mathrm{yr}$ $(\mathrm{NPP}=\mathrm{Rh}+\mathrm{NEP})$. If we apply the simple model $(\mathrm{Rs}=1.24 \mathrm{NPP}+24.5)$ developed by Raich and Schlesinger (1992), then we obtain an Rs flux of 98.2 $\mathrm{PgC} / \mathrm{yr}$, which is very close to the recent estimate of global Rs of $98 \mathrm{PgC} / \mathrm{yr}$ by Bond-Lamberty and Thomson (2010b) using an empirical model and slightly larger than the estimate of $91 \mathrm{PgC} / \mathrm{yr}$ by Hashimoto et al. (2015).

The large differences among the earth system models in estimating global Rh suggest that the current process-based models are not "perfect" either in estimating global Rs. Different model structures and parameters are the key sources that result in the discrepancy. However, the deep coupling of multiple processes in the models means that the process-based models are usually more consistent in space and time than the empirical models.

In summary, the global Rs flux has been estimated ranging from $50 \mathrm{PgC} / \mathrm{yr}$ to about $100 \mathrm{PgC} / \mathrm{yr}$ in various studies using different methods. Large uncertainties on estimating global Rs flux have been evidenced not only among the studies but within each study as well. For most of the studies, the accuracy of estimating global Rs ranged from about $70 \%$ to $95 \%$. Further efforts on measuring and modeling Rs are needed to improve the accuracy for better constraining the global carbon budgets. With rapidly increasing measurements of Rs in the world, future modeling efforts on global Rs should take advantage of data cleansing, data mining, and data-model fusion techniques with advances in data science and cloud computation.

\section{Contribution of Rs to global carbon budgets}

The Rs plays a critical role in the global carbon budget. Using the results from Bond-Lamberty and Thomson (2010b), Hashimoto et al. (2015) and the global GPP and NPP data of the MODIS products, we found global Rs accounts for $85-90 \%$ of the global GPP and that Rs is 1.76-1.87 times of global NPP (2000-2012). This means that, at global scale, $85-90 \%$ of the GPP is allocated to belowground 
Table 2

Comparison of global soil respiration with GPP and NPP.

\begin{tabular}{|c|c|c|c|c|c|c|c|c|}
\hline \multirow[t]{2}{*}{ Year } & \multicolumn{2}{|l|}{ MODIS } & \multicolumn{3}{|c|}{ Bond-Lamberty and Thomson (2010b) } & \multicolumn{3}{|c|}{ Hashimoto et al. (2015) } \\
\hline & $\begin{array}{l}\text { GPP } \\
\text { (PgC/yr) }\end{array}$ & $\begin{array}{l}\text { NPP } \\
\text { (PgC/yr) }\end{array}$ & $\begin{array}{l}\text { Rs } \\
\text { (PgC/yr) }\end{array}$ & Rs/GPP & RS/NPP & $\begin{array}{l}\text { Rs } \\
(\mathrm{PgC} / \mathrm{yr})\end{array}$ & Rs/GPP & RS/NPP \\
\hline 2000 & 110.00 & 54.05 & 97.3 & 0.885 & 1.800 & 92.4 & 0.840 & 1.709 \\
\hline 2001 & 109.49 & 53.21 & 98.4 & 0.899 & 1.849 & 93.2 & 0.851 & 1.751 \\
\hline 2002 & 108.09 & 51.86 & 98.9 & 0.915 & 1.907 & 91.9 & 0.850 & 1.772 \\
\hline 2003 & 109.16 & 52.65 & 98.7 & 0.904 & 1.875 & 94.2 & 0.863 & 1.789 \\
\hline 2004 & 110.63 & 53.90 & 98.3 & 0.889 & 1.824 & 93.5 & 0.845 & 1.735 \\
\hline 2005 & 107.63 & 51.03 & 99.5 & 0.924 & 1.950 & 93.1 & 0.865 & 1.824 \\
\hline 2006 & 109.91 & 52.92 & 98.8 & 0.899 & 1.867 & 93.6 & 0.852 & 1.769 \\
\hline 2007 & 109.66 & 52.50 & 99.3 & 0.906 & 1.891 & 92.8 & 0.846 & 1.768 \\
\hline 2008 & 109.37 & 53.10 & & & & 92.4 & 0.845 & 1.740 \\
\hline 2009 & 109.51 & 53.21 & & & & 92.7 & 0.847 & 1.742 \\
\hline 2010 & 109.73 & 52.57 & & & & 95.1 & 0.867 & 1.809 \\
\hline 2011 & 111.04 & 54.56 & & & & 93.9 & 0.846 & 1.721 \\
\hline 2012 & 109.09 & 52.87 & & & & 93.2 & 0.854 & 1.763 \\
\hline Mean & 109.49 & 52.96 & 98.65 & 0.90 & 1.87 & 93.23 & 0.85 & 1.76 \\
\hline
\end{tabular}

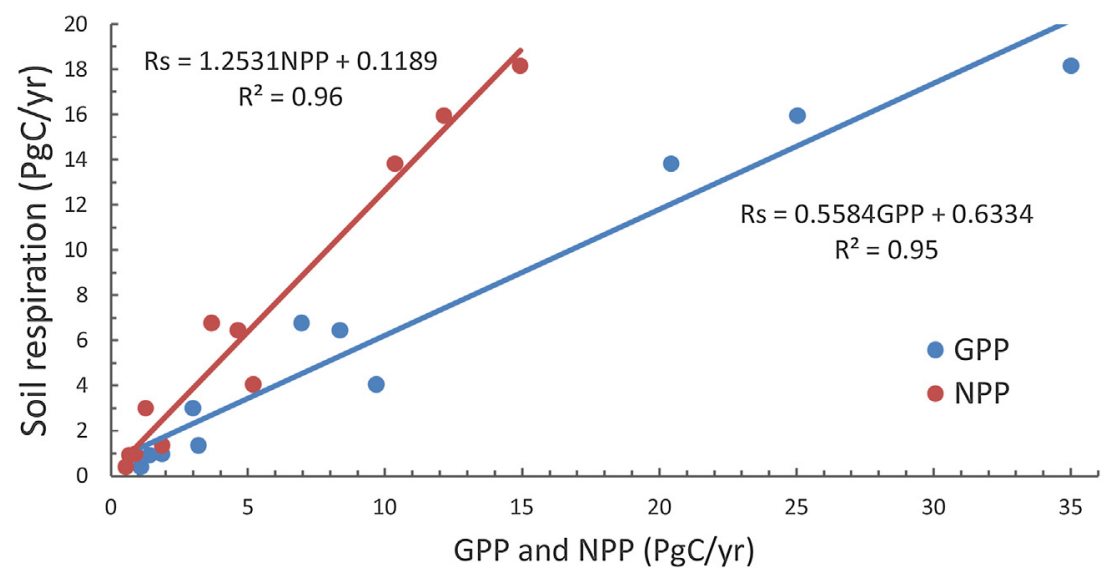

Fig. 4. Relationships between global annual soil respiration and GPP and NPP.

through roots and aboveground litter fall (Table 2 ). The Rs/NPP ratio indicates that at global scale about $76-87 \%$ of NPP is allocated to root respiration. In addition, we also found that the Rs/GPP and Rs/NPP ratios were very consistent among years with a coefficient of variation $(\mathrm{CV})<1.33 \%$ for the Rs/GPP ratio and a $\mathrm{CV}<2.37 \%$ for Rs/NPP.

Raich and Schlesinger (1992) found that global Rs flux was highly correlated with global NPP at biome level. In the current study we used the Raich et al. (2002) model and estimated the Rs fluxes for the major biomes using the MODIS vegetation map. We also found that the Rs flux was highly correlated with both NPP $\left(R^{2}=0.96\right)$ and GPP $\left(R^{2}=0.95\right)$ at biome scale (Fig. 4). Interestingly, the slope of 1.25 in the regression equation between Rs and NPP is almost the same as in Raich and Schlesinger (1992), who used the statistical approach to estimate global Rs flux. The high correlation coefficients suggest that the global Rs might be roughly estimated by global NPP or GPP based on a simple regression model.

Previous studies also found that global warming feedback through ecosystem respiration, mainly soil respiration, could significantly increase future atmospheric $\mathrm{CO}_{2}$ concentration and thus global temperatures (Cox et al., 2000; Heimann and Reichstein, 2008). However, the magnitude of the feedback effect was quite different among various models due partly to the temperature sensitivity $\left(\mathrm{Q}_{10}\right)$ of Rs. Although the $\mathrm{Q}_{10}$ has drawn a lot of attention in the past few years, there is no consensus among the modeling communities about the best way to improve the $\mathrm{Q}_{10}$ function in ecosystem and earth system models. In addition to the global scale, previous studies also found that Rs regulated NEP at the regional scale, such as in Europe and China (Valentini et al., 2000; Reichstein et al., 2007; Yu et al., 2013).

\section{Conclusions and recommendations}

\subsection{Conclusions}

So far, there are about 4263 measurements of annual Rs at 1120 sites across the globe with most of the measurements in North America, Western Europe, and East Asia. The uneven distribution of the Rs data has limited the application of the data in estimating global Rs flux. The traditional soil collar wall blocks $\mathrm{CO}_{2}$ diffusion from deeper soils when measuring Rs on slopes. The obliquely-cut soil collars can avoid this problem and thus are recommended for measuring Rs on slope soils. Current estimations of global Rs is subject to large uncertainties disregarding the scaling-up or modeling methods. Soil respiration accounts for $85-90 \%$ of global GPP, suggesting that $85-90 \%$ of photosynthate is allocated to belowground at a global scale. The global Rs/NPP ratio is $1.76-1.87$, indicating that root respiration accounts for $76-87 \%$ of global NPP.

\subsection{Improving Rs measurements}

More Rs measurements are needed in Africa, East Europe, North Asia, Southeast Asia, and Central Australia where few measurements are currently available. Priority should also be given to measuring Rs in deserts, savannas, shrublands, and wetlands due to the very limited number of Rs measurements in those ecosystems. Collaborations with researchers in those regions to measure 
Rs are highly recommended. Large chambers are needed to boost sampling efficiency, especially in rocky soils where rocks prevent the installation of small chambers or soil collars, while automatic chambers are encouraged to enhance the sampling frequency, especially in harsh environments where Rs is highly dynamic. Obliquely-cut soil collars are recommended to measure Rs on steep slopes and vertical-projection-area corrections are needed for measuring Rs on slopes using the $\mathrm{CO}_{2}$ gradient method. New technologies, such as smart soil chambers, robots, and drones can also be explored to facilitate Rs measurements in remote and difficult-access ecosystems where Rs measurements have been rarely conducted.

\subsection{Improving Rs modeling}

Data sharing is essential to improving Rs models, so the global soil respiration community should promote data sharing by establishing online portals for downloading and uploading Rs data. Using high-resolution climate data to drive Rs models is essential to improving the estimation of global Rs flux. The Rs fluxes estimated by the process models, both ecosystem and earth system models, should be reported in relevant publications. Big data technologies, such as data cleansing, data mining, data-model fusion, and cloud computation will help improve global Rs modeling, especially the process-based models. Temperature sensitivity deserves more attention due to its critical role in linking soil respiration to climate change feedback.

\section{Acknowledgements}

We thank Fen Zhao for helping with processing the MODIS GPP and NPP data and Steven Xu for improving the English of the manuscript. This work was financially supported by the National Basic Research Program of China (973 Program, 2012CB417103) and the UNDP-Global Environment Facility Project (Strengthening Effectiveness of the Protected Area System in Qinghai Province, China to Conserve Globally Important Biodiversity, GEF Project ID 3992). We also thank Dr. Ben Bond-Lamberty and an anonymous reviewer for their constructive comments and suggestions in revising the manuscript.

\section{References}

Abbasi, M.K., Müller, C., 2011. Trace gas fluxes of $\mathrm{CO}_{2}, \mathrm{CH}_{4}$ and $\mathrm{N}_{2} \mathrm{O}$ in a permanent grassland soil exposed to elevated $\mathrm{CO}_{2}$ in the Giessen FACE study. Atmos. Chem. Phys. 11, 9333-9342.

Angert, A., Muhr, J., Juarez, R.N., Muñoz, W.A., Kraemer, G., Santillan, J.R., Barkan, E., Mazeh, S., Chambers, J.Q., Trumbore, S.E., 2012. Internal respiration of Amazon tree stems greatly exceeds external $\mathrm{CO}_{2}$ efflux. Biogeosciences 9, 4979-4991.

Angert, A., Yakir, D., Rodeghiero, M., Preisler, Y., Davidson, E.A., Weiner, T., 2015. Using $\mathrm{O} 2$ to study the relationships between soil CO2 efflux and soil respiration. Biogeosciences 12, 2089-2099.

Aubrey, D.P., Teskey, R.O., 2009. Root-derived $\mathrm{CO}_{2}$ efflux via xylem stream rivals soil $\mathrm{CO}_{2}$ efflux. New Phytol. 184, 35-40.

Austin, A.T., Vivanco, L., 2006. Plant litter decomposition in a semi-arid ecosystem controlled by photodegradation. Nature 442, 555-558.

Ball, B.C., Scott, A., Parker, J.P., 1999. Field $\mathrm{N}_{2} \mathrm{O}, \mathrm{CO}_{2}$ and $\mathrm{CH}_{4}$ fluxes in relation to tillage: compaction and soil quality in Scotland. Soil Tillage Res. 53, 29-39.

Barnard, R.L., Osborne, C.A., Firestone, M.K., 2014. Changing precipitation pattern alters soil microbial community response to wet-up under a Mediterranean-type climate. ISME J. 9, 946-957.

Bekku, Y., Koizumi, H., Oikawa, T., Iwaki, H., 1997. Examination of four methods for measuring soil respiration. Appl. Soil Ecol. 5, 247-254.

Benner, R., Newell, S.Y., Maccubbin, A.E., Hodson, R.E., 1984. Relative contributions of bacteria and fungi to rates of degradation of lignocellulosic detritus in salt-marsh sediments. Appl. Environ. Microbiol. 48, 36-40.

Berg, B., Laskowski, R., 2005. Litter fall. Adv. Ecol. Res. 38, 19-71.

Bloemen, J., McGuire, M.A., Aubrey, D.P., Teskey, R.O., Steppe, K., 2013. Transport of root-respired $\mathrm{CO}_{2}$ via the transpiration stream affects aboveground carbon assimilation and $\mathrm{CO}_{2}$ efflux in trees. New Phytol. 197, 555-565.

Bocock, K.L., 1964. Changes in the amounts of dry matter, nitrogen, carbon and energy in decomposing woodland leaf litter in relation to the activities of the soil fauna. J. Ecol. 52, 273.
Bond-Lamberty, B., Thomson, A., 2010a. A global database of soil respiration data. Biogeosciences 7, 1915-1926.

Bond-Lamberty, B., Thomson, A., 2010b. Temperature-associated increases in the global soil respiration record. Nature 464, 579-582.

Bond-Lamberty, B.P., Thomson, A.M., 2014. A Global Database of Soil Respiration Data, Version 3.0. Data Set. Oak Ridge National Laboratory Distributed Active Archive Center, Oak Ridge, Tennessee, USA, Available on-line http://dx.doi.org/ 10.3334/ORNLDAAC/1235.

Bond-Lamberty, B., Wang, C., Gower, S.T., 2004. Contribution of root respiration to soil surface $\mathrm{CO}_{2}$ flux in a boreal black spruce chronosequence. Tree Physiol. 24 1387-1395.

Boone, R.D., Nadelhoffer, K.J., Canary, J.D., Kaye, J.P., 1998. Roots exert a strong influence on the temperature sensitivity of soil respiration. Nature 396, 570-572.

Boshoff, M., De Jonge, M., Dardenne, F., Blust, R., Bervoets, L., 2014. The impact of metal pollution on soil faunal and microbial activity in two grassland ecosystems. Environ. Res. 134, 169-180.

Bridgham, S.D., Richardson, C.J., 1992. Mechanisms controlling soil respiration $\left(\mathrm{CO}_{2}\right.$ and $\left.\mathrm{CH}_{4}\right)$ in southern peatlands. Soil Biol. Biochem. 24, 1089-1099.

Brussaard, L., 1998. Soil fauna, guilds, functional groups and ecosystem processes. Appl. Soil Ecol. 9, 123-135.

Calhoun, M.W., Oden, K.L., Gennis, R.B., De Mattos, M.J., Neijssel, O.M., 1993. Energetic efficiency of Escherichia coli: effects of mutations in components of the aerobic respiratory chain. J. Bacteriol. 175, 3020-3025.

Chen, S., Zou, J., Hu, Z., Chen, H., Lu, Y., 2014. Global annual soil respiration in relation to climate, soil properties and vegetation characteristics: summary of available data. Agric. For. Meteorol. 198, 335-346.

Cheng, W., 1996. Measurement of rhizosphere respiration and organic matter decomposition using natural ${ }^{13} \mathrm{C}$. Plant Soil 183, 263-268.

Chiang, P.N., Yu, J.C., Wang, Y.N., Lai, Y.J., 2014. May: different tree species affect soil respiration spatial distribution in a subtropical forest of southern Taiwan. EGU General Assembly Conference Abstracts 16, 2533.

Cong, J., Yang, Y., Liu, X., Lu, H., Liu, X., Zhou, J., Li, D., Yin, H., Ding, J., Zhang, Y., 2015. Analyses of soil microbial community compositions and functional genes reveal potential consequences of natural forest succession. Sci. Rep. 5, 10007.

Cox, P.M., Betts, R.A., Jones, C.D., Spall, S.A., Totterdell, I.J., 2000. Acceleration of global warming due to carbon-cycle feedbacks in a coupled climate model. Nature 408, 184-187.

Darbishire, F.V., Russell, E.J., 1907. Oxidation in soils and its relation to productiveness. Part II. The influence of partial sterilisation. J. Agric. Sci. 2, 305.

Davidson, E.A., Janssens, I.A., 2006. Temperature sensitivity of soil carbon decomposition and feedbacks to climate change. Nature 440, 165-173.

Davidson, E.A., Savage, K., Bolstad, P., Clark, D.A., Curtis, P.S., Ellsworth, D.S., Hanson, P.J., Law, B.E., Luo, Y., Pregitzer, K.S., Randolph, J.C., 2002a. Belowground carbon allocation in forests estimated from litterfall and IRGA-based soil respiration measurements. Agric. For. Meteorol. 113, 39-51.

Davidson, E.A., Savage, K.V.L.V., Verchot, L.V., Navarro, R., 2002b. Minimizing artifacts and biases in chamber-based measurements of soil respiration. Agric. For. Meteorol. 113, 21-37.

Davidson, E.A., Janssens, I.A., Luo, Y., 2006. On the variability of respiration in terrestrial ecosystems: moving beyond $Q_{10}$. Global Change Biol. 12, 154-164.

De Jong, E., Schappert, H.J.V., 1972. Calculation of soil respiration and activity from $\mathrm{CO}_{2}$ profiles in the soil. Soil Sci. 113, 328-333.

Dick, W.A., Tabatabai, M., 1984. Kinetic parameters of phosphatases in soils and organic waste materials. Soil Sci. 137, 7-15.

Elliott, E.T., 1986. Aggregate structure and carbon nitrogen, and phosphorus in native and cultivated soils. Soil Sci. Soc. Am. J. 50, 627-633.

Emmerich, W.E., 2003. Carbon dioxide fluxes in a semiarid environment with high carbonate soils. Agric. For. Meteorol. 116, 91-102.

Epule, T.E., 2015. A new compendium of soil respiration data for Africa. Challanges 6, 88-97.

Ewel, K.C., Cropper Jr, W.P., Gholz, H.L., 1987. Soil $\mathrm{CO}_{2}$ evolution in Florida slash pine plantations. I. Changes through time. Can. J. For. Res. 17, 325-329.

Fan, Z., Neff, J.C., Waldrop, M.P., Ballantyne, A.P., Turetsky, M.R., 2014. Transport of oxygen in soil pore-water systems: implications for modeling emissions of carbon dioxide and methane from peatlands. Biogeochemistry 121, 455-470.

Friedlingstein, P., Cox, P., Betts, R., Bopp, L., Von Bloh, W., Brovkin, V., Cadule, P., Doney, S., Eby, M., Fung, I., Bala, G., 2006. Climate-carbon cycle feedback analysis: results from the C4MIP model intercomparison. J. Clim. 19, 3337-3353.

Friedlingstein, P., Meinshausen, M., Arora, V.K., Jones, C.D., Anav, A., Liddicoat, S.K., Knutti, R., 2014. Uncertainties in CMIP5 climate projections due to carbon cycle feedbacks. J. Clim. 27, 511-526.

Gainey, P.L., 1919. Parallel formation of carbon dioxide, ammonia and nitrate in soil. Soil Sci. 7, 293-311.

Grogan, P., 1998. $\mathrm{CO}_{2}$ flux measurement using soda lime: correction for water formed during $\mathrm{CO}_{2}$ adsorption. Ecology 79, 1467-1468.

Gupta, V.V.S.R., Farrell, R.E., Germida, J.J., 1993. Activity of arylsulfatase in Saskatchewan soils. Can. J. Soil Sci. 73, 341-347.

Hättenschwiler, S., Tiunov, A.V., Scheu, S., 2005. Biodiversity and litter decomposition in terrestrial ecosystems. Annu. Rev. Ecol. Evol. Syst. 36, $191-218$

Högberg, P., Nordgren, A., Buchmann, N., Taylor, A.F., Ekblad, A., Högberg, M.N., Nyberg, G., Ottosson-Löfvenius, M., Read, D.J., 2001. Large-scale forest girdling 
shows that current photosynthesis drives soil respiration. Nature 411 , 789-792

Han, T., Huang, W., Liu, J., Zhou, G., Xiao, Y., 2015. Different soil respiration responses to litter manipulation in three subtropical successional forests. Sci. Rep. 5, 18166.

Hanson, P.J., Edwards, N.T., Garten, C.T., Andrews, J.A., 2000. Separating root and soil microbial contributions to soil respiration: a review of methods and observations. Biogeochemistry 48, 115-146.

Harmon, M.E., Silver, W.L., Fasth, B., Chen, H.U.A., Burke, I.C., Parton, W.J., Hart, S.C. Currie, W.S., 2009. Long-term patterns of mass loss during the decomposition of leaf and fine root litter: an intersite comparison. Global Change Biol. 15, 1320-1338.

Hartley, I.P., Ineson, P., 2008. Substrate quality and the temperature sensitivity of soil organic matter decomposition. Soil Biol. Biochem. 40, 1567-1574

Hartmann, M., Frey, B., Mayer, J., Mäder, P., Widmer, F., 2015. Distinct soil microbial diversity under long-term organic and conventional farming. ISME J. 9, 1177-1194.

Hashimoto, S., Carvalhais, N., Ito, A., Migliavacca, M., Nishina, K., Reichstein, M., 2015. Global spatiotemporal distribution of soil respiration modeled using a global database. Biogeosciences 12, 4121-4132.

Hastings, S.J., Oechel, W.C., Muhlia-Melo, A., 2005. Diurnal, seasonal and annual variation in the net ecosystem $\mathrm{CO}_{2}$ exchange of a desert shrub community (Sarcocaulescent) in Baja California, Mexico. Global Change Biol. 11, 927-939.

Heimann, M., Reichstein, M., 2008. Terrestrial ecosystem carbon dynamics and climate feedbacks. Nature 451, 289-292.

Hibbard, K.A., Law, B.E., Reichstein, M., Sulzman, J., 2005. An analysis of soil respiration across northern hemisphere temperate ecosystems. Biogeochemistry 73, 29-70.

Houghton, R.A., Woodwell, G.M., 1989. Global climatic change. Sci. Am. 260, 36-44

Huang, N., He, J.S., Niu, Z., 2013. Estimating the spatial pattern of soil respiration in Tibetan alpine grasslands using Landsat TM images and MODIS data. Ecol. Indic. 26, 117-125.

IPCC, 2000. In: Watson, Robert T., Noble, Ian R., Bolin, Bert, Ravindranath, N.H. Verardo, David J., Dokken, David J. (Eds.), Land Use, Land-Use Change and Forestry. Cambridge University Press, UK, p. 375.

IPCC, 2013. Climate Change 2013: The Physical Science Basis, Contribution of Working Group I to the Fifth Assessment Report of the Intergovernmental Panel on Climate Change. Cambridge University Press, Cambridge, United Kingdom/New York, NY, USA

Ilangovan, K., Vivekanandan, M., 1992. Effect of oil pollution on soil respiration and growth of Vigna mungo (L) Hepper. Sci. Total Environ. 116, 187-194.

Ishidoya, S., Murayama, S., Takamura, C., Kondo, H., Saigusa, N., Goto, D., Morimoto, S., Aoki, N., Aoki, S., Nakazawa, T., 2013. $\mathrm{O}_{2}: \mathrm{CO}_{2}$ exchange ratios observed in a cool temperate deciduous forest ecosystem of central Japan. Tellus B, 65.

Jennings, B.W., Watmough, S.A., 2015. The impact of invasive earthworms on soil respiration and soil carbon within temperate hardwood forests. Ecosystems 19, 942-954.

Kätterer, T., Reichstein, M., Andrén, O., Lomander, A., 1998. Temperature dependence of organic matter decomposition: a critical review using literature data analyzed with different models. Biol. Fertil. Soils 27, 258-262.

Kane, E.S., Chivers, M.R., Turetsky, M.R., Treat, C.C., Petersen, D.G., Waldrop, M., Harden, J.W., McGuire, A.D., 2013. Response of anaerobic carbon cycling to water table manipulation in an Alaskan rich fen. Soil Biol. Biochem. 58, 50-60.

Keith, H., Wong, S.C., 2006. Measurement of soil $\mathrm{CO}_{2}$ efflux using soda lime absorption: both quantitative and reliable. Soil Biol. Biochem. 38, 1121-1131.

Kirschbaum, M.U., 1995. The temperature dependence of soil organic matter decomposition, and the effect of global warming on soil organic $\mathrm{C}$ storage. Soil Biol. Biochem. 27, 753-760.

Knoepp, J.D., Vose, J.M., 2002. Quantitative comparison of in situ soil CO2 flux measurement method. USDA Forest Service, Southern Research Station. Research Paper SRS-28.

Krauss, K.W., Whitbeck, J.L., Howard, R.J., 2012. On the relative roles of hydrology, salinity, temperature, and root productivity in controlling soil respiration from coastal swamps (freshwater). Plant Soil 358, 265-274

Kuzyakov, Y., Cheng, W., 2001. Photosynthesis controls of rhizosphere respiration and organic matter decomposition. Soil Biol. Biochem. 33, 1915-1925.

Le Quéré, C., Moriarty, R., Andrew, R.M., Peters, G.P., Ciais, P., Friedlingstein, P. Jones, S.D., Sitch, S., Tans, P., Arneth, A., Boden, T.A., 2015. Global carbon budget 2014.

Lee, K.E., Foster, R.C., 1991. Soil fauna and soil structure. Soil Res. 29, 745-775.

Legates, D.R., Willmott, C.J., 1990a. Mean seasonal and spatial variability in global surface air temperature. Theor. Appl. Climatol. 41, 11-21.

Legates, D.R., Willmott, C.J., 1990b. Mean seasonal and spatial variability in gauge-corrected global precipitation. Int. J. Climatol. 10,111-127.

Liang, G., Liu, X., Chen, X., Qiu, Q., Zhang, D., Chu, G., Liu, J., Liu, S., Zhou, G., 2013. Response of soil respiration to acid rain in forests of different maturity in southern China. PLoS One 8, 62207.

Liu, L., Xu, M., 2015. Microbial biomass in sediments affects greenhouse gas effluxes in Poyang Lake in China. J. Freshwater Ecol. 31, 109-121.

Lundegårdh, H., 1927. Carbon dioxide evolution of soil and crop growth. Soil Sci. 23, 417-453.

Ma, J., Wang, Z.Y., Stevenson, B.A., Zheng, X.J., Li, Y., 2013. An inorganic $\mathrm{CO}_{2}$ diffusion and dissolution process explains negative $\mathrm{CO}_{2}$ fluxes in saline/alkaline soils. Sci. Rep. 3.

Makoi, J.H., Ndakidemi, P.A., 2008. Selected soil enzymes: examples of their potential roles in the ecosystem. Afr. J. Biotechnol. 7.
Melillo, J.M., McGuire, A.D., Kicklighter, D.W., Moore, B., Vorosmarty, C.J., Schloss, A.L., 1993. Global climate change and terrestrial net primary production. Nature 363, 234-240.

Mencuccini, M., Hölttä, T., 2010. The significance of phloem transport for the speed with which canopy photosynthesis and belowground respiration are linked. New Phytol. 185, 189-203.

Mikan, C.J., Schimel, J.P., Doyle, A.P., 2002. Temperature controls of microbial respiration in arctic tundra soils above and below freezing. Soil Biol. Biochem. 34, 1785-1795.

Moyes, A.B., Gaines, S.J., Siegwolf, R.T., Bowling, D.R., 2010. Diffusive fractionation complicates isotopic partitioning of autotrophic and heterotrophic sources of soil respiration. Plant Cell Environ. 33, 1804-1819.

Nay, S.M., Mattson, K.G., Bormann, B.T., 1994. Biases of chamber methods for measuring soil $\mathrm{CO}_{2}$ efflux demonstrated with a laboratory apparatus. Ecology $75,2460-2463$.

Norman, J.M., Garcia, R., Verma, S.B., 1992. Soil surface $\mathrm{CO}_{2}$ fluxes and the carbon budget of a grassland. J. Geophys. Res.: Atmos. 97, 18845-18853.

Norman, J.M., Kucharik, C.J., Gower, S.T., Baldocchi, D.D., Crill, P.M., Rayment, M., Savage, K., Strieglfi, R.G., 1997. A comparison of six methods for measuring soil-surface carbon dioxide fluxes. J. Geophys. Res. 102, 28-771.

Parton, W.J., Scurlock, J.M.O., Ojima, D.S., Gilmanov, T.G., Scholes, R.J., Schimel, D.S. Kirchner, T., Menaut, J.C., Seastedt, T., Garcia Moya, E., Kamnalrut, A., 1993. Observations and modeling of biomass and soil organic matter dynamics for the grassland biome worldwide. Global Biogeochem. Cycles 7, 785-809.

Pendall, E., Bridgham, S., Hanson, P.J., Hungate, B., Kicklighter, D.W., Johnson, D.W., Law, B.E., Luo, Y., Megonigal, J.P., Olsrud, M., Ryan, M.G., 2004. Below-ground process responses to elevated $\mathrm{CO}_{2}$ and temperature: a discussion of observations, measurement methods, and models. New Phytol. 162, 311-322.

Petersen, H., Luxton, M., 1982. A comparative analysis of soil fauna populations and their role in decomposition processes. Oikos 39, 288-388.

Pingintha, N., Leclerc, M.Y., Beasley Jr., John, Zhang, G., Senthong, C., 2010. Assessment of the soil $\mathrm{CO}_{2}$ gradient method for soil $\mathrm{CO}_{2}$ efflux measurements: comparison of six models in the calculation of the relative gas diffusion coefficient. Tellus B 62, 47-58.

Pitombo, L.M., Carmo, J.B., Hollander, M., Rossetto, R., López, M.V., Cantarella, H., Kuramae, E.E., 2015. Exploring soil microbial 16S rRNA sequence data to increase carbon yield and nitrogen efficiency of a bioenergy crop. Global Change Biol. Bioenergy 8, 867-879.

Pongracic, S., Kirschbaum, M.U.F., Raison, R.J., 1997. Comparison of soda lime and infrared gas analysis techniques for in situ measurement of forest soil respiration. Can. J. For. Res. 27, 1890-1895.

Post, W.M., Emanuel, W.R., Zinke, P.J., Stangenberger, A.G., 1982. Soil carbon pools and world life zones. Nature 298, 156-159.

Qi, Y., Xu, M., 2001. Separating the effects of moisture and temperature on soil CO2 efflux in a coniferous forest in the Sierra Nevada mountains. Plant Soil 237. 15-23.

Raich, J.W., Potter, C.S., 1995. Global patterns of carbon dioxide emissions from soils. Global Biogeochem. Cycles 9, 23-36.

Raich, J.W., Schlesinger, W.H., 1992. The global carbon dioxide flux in soil respiration and its relationship to vegetation and climate. Tellus B 44, 81-99.

Raich, J.W., Tufekciogul, A., 2000. Vegetation and soil respiration: correlations and controls. Biogeochemistry 48, 71-90.

Raich, J.W., Potter, C.S., Bhagawati, D., 2002. Interannual variability in global soil respiration, 1980-94. Global Change Biol. 8, 800-812.

Reichstein, M., Papale, D., Valentini, R., Aubinet, M., Bernhofer, C., Knohl, A., Laurila, T., Lindroth, A., Moors, E., Pilegaard, K., Seufert, G., 2007. Determinants of terrestrial ecosystem carbon balance inferred from European eddy covariance flux sites. Geophys. Res. Lett. 34.

Rey, A., 2015. Mind the gap: non-biological processes contributing to soil $\mathrm{CO}_{2}$ efflux. Global Change Biol. 21, 1752-1761.

Rivkina, E.M., Friedmann, E.I., McKay, C.P., Gilichinsky, D.A., 2000. Metabolic activity of permafrost bacteria below the freezing point. Appl. Environ. Microbiol. 66, 3230-3233.

Rochette, P., Flanagan, L.B., 1997. Quantifying rhizosphere respiration in a corn crop under field conditions. Soil Sci. Soc. Am. J. 61, 466-474.

Rochette, P., Desjardins, R.L., Gregorich, E.G., Pattey, E., Lessard, R., 1992. Soil respiration in barley (Hordeum vulgare L) and fallow fields. Can. J. Soil Sci. 72 591-603.

Rochette, P., Ellert, B., Gregorich, E.G., Desjardins, R.L., Pattey, E., Lessard, R., Johnson, B.G., 1997. Description of a dynamic closed chamber for measuring soil respiration and its comparison with other techniques. Can. J. Soil Sci. 77, 195-203.

Roland, M., Serrano-Ortiz, P., Kowalski, A.S., Goddéris, Y., Sánchez-Cañete, E.P., Ciai, P., Domingo Poveda, F., Cuezva, S., Sánchez-Moral, S., Longdoz, B., Yakir, D., 2013. Atmospheric turbulence triggers pronounced diel pattern in karst carbonate geochemistry. Biogeosci. Discuss. 10, 1207-1227.

Romaní, A.M., Fischer, H., Mille-Lindblom, C., Tranvik, L.J., 2006. Interactions of bacteria and fungi on decomposing litter: differential extracellular enzyme activities. Ecology 87, 2559-2569.

Running S.W. Hunt Jr. E.R., 1993. In: Ehleringer, J.R., Field, C.B. (Eds.), Generalization of a Forest Ecosystem Process Model for Other Biomes, BIOME-BGC, and an Application for Global-Scale Models. Scaling Physiological Processes: Leaf to Globe. Academic Press, San Diego, pp. 141-157.

Rustad, L.E., Huntington, T.G., Boone, R.D., 2000. Controls on soil respiration: implications for climate change. Biogeochemistry 48, 1-6. 
Rustad, L.E.J.L., Campbell, J., Marion, G., Norby, R., Mitchell, M., Hartley, A Cornelissen, J., Gurevitch, J., 2001. A meta-analysis of the response of soil respiration, net nitrogen mineralization, and aboveground plant growth to experimental ecosystem warming. Oecologia 126, 543-562.

Ryan, M.G., Law, B.E., 2005. Interpreting, measuring, and modeling soil respiration. Biogeochemistry 73, 3-27.

Sauer, N., Baier, K., Gahrtz, M., Stadler, R., Stolz, J., Truernit, E., 1994. Sugar transport across the plasma membranes of higher plants. Plant Mol. Biol. 26, 1671-1679.

Sayer, E.J., Powers, J.S., Tanner, E.V., 2007. Increased litterfall in tropical forests boosts the transfer of soil $\mathrm{CO}_{2}$ to the atmosphere. PLoS One 2, 1299.

Scharlemann, J.P., Tanner, E.V., Hiederer, R., Kapos, V., 2014. Global soil carbon: understanding and managing the largest terrestrial carbon pool. Carbon Manage. 5, 81-91.

Schlesinger, W.H., Andrews, J.A., 2000. Soil respiration and the global carbon cycle. Biogeochemistry 48, 7-20.

Schlesinger, W.H., Belnap, J., Marion, G., 2009. On carbon sequestration in desert ecosystems. Global Change Biol. 15, 1488-1490.

Schlesinger, W.H., 1977. Carbon balance in terrestrial detritus. Annu. Rev. Ecol. Syst. 8, 51-81.

Schroeter, B., Green, T.G.A., Kappen, L., Seppelt, R.A., 1994. Carbon dioxide exchange at subzero temperatures: field measurements on Umbilicaria aprina in Antarctica. CryptBot 4, 233-241.

Seibt, U., Brand, W.A., Heimann, M., Lloyd, J., Severinghaus, J.P., Wingate, L., 2004. Observations of $\mathrm{O}_{2}: \mathrm{CO}_{2}$ exchange ratios during ecosystem gas exchange. Global Biogeochem. Cycles 18.

Shao, P., Zeng, X., Moore, D.J., Zeng, X., 2013. Soil microbial respiration from observations and Earth System Models. Environ. Res. Lett. 8, 034034.

Six, J., Elliott, E.T., Paustian, K., Doran, J.W., 1998. Aggregation and soil organic matter accumulation in cultivated and native grassland soils. Soil Sci. Soc. Am. J. 62, 1367-1377.

Skopp, J., Jawson, M.D., Doran, J.W., 1990. Steady-state aerobic microbial activity as a function of soil water content. Soil Sci. Soc. Am. J. 54, 1619-1625.

Smith, F.B., Brown, P.E., 1931. Soil respiration. J. Am. Soc. Agron. 23, 909-916.

Sorensen, L.I., Holmstrup, M., Maraldo, K., Christensen, S., Christensen, B., 2006. Soil fauna communities and microbial respiration in high Arctic tundra soils at Zackenberg, Northeast Greenland. Polar Biol. 29, 189-195.

Stevenson, B.A., Verburg, P.S.J., 2006. Effluxed $\mathrm{CO}_{2}{ }^{-13} \mathrm{C}$ from sterilized and unsterilized treatments of a calcareous soil. Soil Biol. Biochem. 38, 1727-1733.

SUBKE, J.A., Inglima, I., Francesca Cotrufo, M., 2006. Trends and methodological impacts in soil $\mathrm{CO}_{2}$ efflux partitioning: a metaanalytical review. Global Change Biol. 12, 921-943.

Szafranek-Nakonieczna, A., Stêpniewska, Z., 2014. Aerobic and anaerobic respiration in profiles of Polesie Lubelskie peatlands. Int. Agrophys. 28 , 219-229.

Tamir, G., Shenker, M., Heller, H., Bloom, P.R., Fine, P., Bar-Tal, A., 2011. Can soil carbonate dissolution lead to overestimation of soil respiration? Soil Sci. Soc. Am. J. 75, 1414-1422.

Tang, J., Baldocchi, D.D., Goldstein, A., Xu, L., 2003. Pulse effects of soil respiration after rain events in California. AGU Fall Meeting Abstracts 1, 05.

Tang, J., Baldocchi, D.D., Xu, L., 2005a. Tree photosynthesis modulates soil respiration on a diurnal time scale. Global Change Biol. 11, 1298-1304.

Tang, J., Misson, L., Gershenson, A., Cheng, W., Goldstein, A.H., 2005b. Continuous measurements of soil respiration with and without roots in a ponderosa pine plantation in the Sierra Nevada Mountains. Agric. For. Meteorol. 132, 212-222.

Torsvik, V., Øvreås, L., 2002. Microbial diversity and function in soil: from genes to ecosystems. Curr. Opin. Microbiol. 5, 240-245.

Truog, E., 1915. Methods for the determination of carbon dioxide and a new form of absorption tower adapted to the titrimetric method. J. Ind. Eng. Chem. 7, 1045-1049.

Valentini, R., Matteucci, G., Dolman, A.J., Schulze, E.D., Rebmann, C., Moors, E.J., Granier, A., Gross, P., Jensen, N.O., Pilegaard, K., Lindroth, A., Grelle, A. Bernhofer, C., Grunwald, T., Aubinet, M., Ceulemans, R., Kowalski, A.S., Vesala, T., Rannik, U., Berbigier, P., Loustau, D., Guomundsson, J., Thorgeirsson, H., Ibrom, A., Morgenstern, K., Clement, R., Moncrieff, J., Montagnani, L., Minerbi, S., Jarvis, P.G., 2000. Respiration as the main determinant of carbon balance in European forests. Nature 404, 861-865.

Vandermeer, J.H., 2011. The Ecology of Agroecosystems. Jones \& Bartlett Learning von Arnold, K., Nilsson, M., Hånell, B., Weslien, P., Klemedtsson, L., 2005. Fluxes of $\mathrm{CO}_{2}, \mathrm{CH}_{4}$ and $\mathrm{N}_{2} \mathrm{O}$ from drained organic soils in deciduous forests. Soil Biol. Biochem. 37, 1059-1071.
Vorobyova, E., Soina, V., Gorlenko, M., Minkovskaya, N., Zalinova, N., Mamukelashvili, A., Gilichinsky, D., Rivkina, E., Vishnivetskaya, T., 1997. The deep cold biosphere: facts and hypothesis. FEMS Microbiol. Rev. 20, 277-290.

Wüthrich, C., Schaub, D., Weber, M., Marxer, P., Conedera, M., 2002. Soil respiration and soil microbial biomass after fire in a sweet chestnut forest in southern Switzerland. Catena 48, 201-215.

Waksman, S.A., Starkey, R.L., 1924. Microbiological analysis of soil as an index of soil fertility. VII. Carbon dioxide evolution. Soil Sci. 17, 141-161.

Wang, Q., He, T., Wang, S., Liu, L., 2013. Carbon input manipulation affects soil respiration and microbial community composition in a subtropical coniferous forest. Agric. For. Meteorol. 178, 152-160.

Wang, B., Zha, T.S., Jia, X., Wu, B., Zhang, Y.Q., Qin, S.G., 2014a. Soil moisture modifies the response of soil respiration to temperature in a desert shrub ecosystem. Biogeosciences 11, 259-268.

Wang, F., Liu, J., Zou, B., Neher, D.A., Zhu, W., Li, Z., 2014b. Species-dependent responses of soil microbial properties to fresh leaf inputs in a subtropical forest soil in South China. Plant Ecol. 7, 86-96.

Wayson, C.A., Randolph, J.C., Hanson, P.J., Grimmond, C.S.B., Schmid, H.P., 2006 Comparison of soil respiration methods in a mid-latitude deciduous forest. Biogeochemistry 80, 173-189.

Werner, C., Brantley, S., 2003. $\mathrm{CO}_{2}$ emissions from the Yellowstone volcanic system. Geochem. Geophys. Geosyst. 4.

Werth, M., Kuzyakov, Y., 2010. ${ }^{13} \mathrm{C}$ fractionation at the root-microorganisms-soil interface: a review and outlook for partitioning studies. Soil Biol. Biochem. 42. 1372-1384.

Whiteley, C.G., Lee, D.J., 2006. Enzyme technology and biological remediation. Enzym. Microb. Technol. 38, 291-316.

Wiant, H.V., 1967. Has the contribution of litter decay to forest. J. For. 65, 408-409.

Wilson, D.B., 2011. Microbial diversity of cellulose hydrolysis. Curr. Opin. Microbiol. 14, 259-263.

Winkler, J.P., Cherry, R.S., Schlesinger, W.H., 1996. The $Q_{10}$ relationship of microbial respiration in a temperate forest soil. Soil Biol. Biochem. 28, 1067-1072.

Wu, C., Gaumont-Guay, D., Black, T.A., Jassal, R.S., Xu, S., Chen, J.M., Gonsamo, A., 2014. Soil respiration mapped by exclusively use of MODIS data for forest landscapes of Saskatchewan, Canada. ISPRS J. Photogramm. Remote Sens. 94, 80-90.

Xie, J., Li, Y., Zhai, C., Li, C., Lan, Z., 2009. $\mathrm{CO}_{2}$ absorption by alkaline soils and its implication to the global carbon cycle. Environ. Geol. 56, 953-961.

Xu, M., Qi, Y., 2001a. Spatial and seasonal variations of $\mathrm{Q}_{10}$ determined by soil respiration measurements at a Sierra Nevadan forest. Global Biogeochem. Cycles 15, 687-696.

$\mathrm{Xu}, \mathrm{M} ., \mathrm{Qi}, \mathrm{Y} ., 2001 \mathrm{~b}$. Soil surface $\mathrm{CO}_{2}$ efflux and its variation in a young ponderosa pine plantation in the Sierra Nevada Mountains, California. Global Change Biol. 7, 667-677.

Xu, M., Chen, J., Brookshire, B.L., 1997. Temperature and its variability in oak forests in the southeastern Missouri Ozarks. Clim. Res. 8, 209-223.

Xu, L., Madsen, R., Anderson, D., Furtaw, M., Garcia, R., McDermitt, D., 2004a. The impact of wind on the soil respiration measurement. InAGU Fall Meeting Abstracts 1, 0935.

Xu, M., Qi, Y., Chen, J., Song, B., 2004b. Scale-dependent relationships between landscape structure and microclimate. Plant Ecol. 173, 39-57.

Yao, H., He, Z.L., Wilson, M., Campbell, C.D., 2000. Microbial biomass and community structure in a sequence of soils with increasing fertility and changing land use. Microb. Ecol. 40, 223-237.

Yim, M.H., Joo, S.J., Nakane, K., 2002. Comparison of field methods for measuring soil respiration: a static alkali absorption method and two dynamic closed chamber methods. For. Ecol. Manage. 170, 189-197.

Yu, G.R., Zhu, X.J., Fu, Y.L., He, H.L., Wang, Q.F., Wen, X.F., Li, X.R., Zhang, L.M., Zhang, L., Su, W., Li, S.G., 2013. Spatial patterns and climate drivers of carbon fluxes in terrestrial ecosystems of China. Global Change Biol. 19, 798-810.

Zhalnina, K., Dias, R., de Quadros, P.D., Davis-Richardson, A., Camargo, F.A., Clark, I.M., McGrath, S.P., Hirsch, P.R., Triplett, E.W., 2015. Soil pH determines microbial diversity and composition in the park grass experiment. Microb. Ecol. 69, 395-406

Zhou, T., Shi, P., Hui, D., Luo, Y., 2009. Global pattern of temperature sensitivity of soil heterotrophic respiration $\left(Q_{10}\right)$ and its implications for carbon-climate feedback. J. Geophys. Res.: Biogeosci. 114.

Zogg, G.P., Zak, D.R., Ringelberg, D.B., White, D.C., MacDonald, N.W., Pregitzer, K.S., 1997. Compositional and functional shifts in microbial communities due to soil warming. Soil Sci. Soc. Am. J. 61, 475-481. 